Article

\title{
Smart Bio-Agents-Activated Sustainable Self-Healing Cementitious Materials: An All-Inclusive Overview on Progress, Benefits and Challenges
}

\author{
Ghasan Fahim Huseien ${ }^{1}$, Moncef L. Nehdi ${ }^{2, *(\mathbb{D})}$, Iman Faridmehr ${ }^{3}{ }^{(D}$, Sib Krishna Ghoshal ${ }^{4}$, Hussein K. Hamzah ${ }^{5}$, \\ Omrane Benjeddou ${ }^{6}$ and Fahed Alrshoudi ${ }^{7}$ (D)
}

1 Department of the Built Environment, College of Design and Engineering, National University of Singapore, Singapore 117566, Singapore; bdggfh@nus.edu.sg

2 Department of Civil Engineering, McMaster University, Hamilton, ON L8S 4M6, Canada

3 Institute of Architecture and Construction, South Ural State University, Lenin Prospect 76, 454080 Chelyabinsk, Russia; faridmekhri@susu.ru

4 Department of Physics, AOMRG \& Laser Centre, Faculty of Science, Universiti Teknologi Malaysia (UTM), Skudai 81310, Malaysia; sibkrishna@utm.my

5 Department of Reinforced Concrete Constructions, Faculty of Civil, Agricultural and Industrial, Technical University of Civil Engineering Bucharest, Bulevardul Lacul Tei 124, Sect. 2, 020396 Bucharest, Romania; hus77top@gmail.com

6 Department of Civil Engineering, College of Engineering, Prince Sattam Bin Abdulaziz University, Alkharj 16273, Saudi Arabia; benjeddou.omrane@gmail.com

7 Department of Civil Engineering, College of Engineering, King Saud University, Riyadh 11421, Saudi Arabia; falrshoudi@ksu.edu.sa

* Correspondence: nehdim@mcmaster.ca

Citation: Huseien, G.F.; Nehdi, M.L.; Faridmehr, I.; Ghoshal, S.K.; Hamzah, H.K.; Benjeddou, O.; Alrshoudi, F. Smart Bio-Agents-Activated Sustainable Self-Healing

Cementitious Materials: An

All-Inclusive Overview on Progress, Benefits and Challenges.

Sustainability 2022, 14, 1980.

https://doi.org/10.3390/su14041980

Academic Editor: Antonio Caggiano

Received: 30 December 2021

Accepted: 29 January 2022

Published: 9 February 2022

Publisher's Note: MDPI stays neutral with regard to jurisdictional claims in published maps and institutional affiliations.

Copyright: (c) 2022 by the authors. Licensee MDPI, Basel, Switzerland. This article is an open access article distributed under the terms and conditions of the Creative Commons Attribution (CC BY) license (https:/ / creativecommons.org/licenses/by/ $4.0 /)$.

\begin{abstract}
Cementitious materials deteriorate progressively with the formation of cracks that occur due to diverse physical, chemical, thermal, and biological processes. Numerous strategies have been adopted to obtain cement-based self-healing materials and determine the novel self-healing mechanisms. The uses of microbes have been established to improve the thickness of the healed crack and mechanical properties of the concrete, a phenomenon seldom addressed in the literature. Based on these factors, this article comprehensively appraises the smart bio-agents-based autonomous healing performance of concrete to demonstrate the recent progress, expected benefits, and ongoing challenges. The fundamentals, design strategies, and efficacy of the smart bio-agents-activated self-healing cementitious materials are the recurring themes of this overview. Furthermore, the effects of various processing parameters on the performance of cementitious self-healing smart bio-agents are discussed in-depth. The achievements, knowledge gaps, and needs for future research in this ever-evolving area for the sustainability and resilience of the built environment are highlighted.
\end{abstract}

Keywords: self-healing; cementitious materials; concrete durability; bio-concrete; sustainability

\section{Introduction}

Concrete is the world's most prevalently utilized construction material due to unparallel compressive strength (CS), affordability, cost-effectiveness, abundance of raw materials, and durability. However, gradual degradation of concrete-based infrastructures is detrimental unless inhibited. The structural integrity and efficacy of concrete degrades due to water penetration into it. The ingress of water, undesired acidic gases, and fluids containing dissolved aggressive chemicals enable the formation of cracks in concrete at the macroand micro-scale [1]. Consequently, the aggressive substances and agents pass through these permeable sites, causing rapid deterioration of concrete. Hence, the durability of concrete and its steel reinforcement are negatively impacted, indicating that the concrete performance in the long-term is decided by the environment wherein concrete structures are placed [2]. Reinforcing steel bars can be oxidized and weakened by the permeation 
of water, oxygen, carbon dioxide and chloride ions. Consequently, the durability of the exposed concrete infrastructure becomes limited [3,4]. Sometimes, the accessibility and repair of certain cracks in concrete is impossible, as they cannot be seen or associated/exist with unfavorable conditions to repair. The number of cracks and their sizes multiply as the materials undergo permeation, contraction, and expansion [5,6]. Consequently, an onus is increasingly placed upon the maintenance and inspection processes for prematurely ageing large portfolio of civil infrastructures. The costs associated with the maintenance are exorbitant, particularly for the large-scale infrastructures, challenging the frequent inspection and maintenance methods. Maintenance and repair can also be tricky due to the difficulty in accessing the damaged site of the infrastructures $[7,8]$. Consequently, academics in the field have increasingly focused upon the marginal capital and labor needs associated with self-healing concrete that can autonomously repair the hazardous cracks. Thus, numerous approaches have been developed to produce novel self-healing concrete, making it capable and prospective for civil engineering constructions.

Total or partial recovery and healing of the materials functionality following the degradation makes up the definition of self-healing materials [9]. Similarly, autonomous repair and identification of the impairment of concrete cracks is another definition of selfhealing materials [10]. Thus, manual intervention can be avoided or minimized within the reparation process [11]. The self-healing concrete is the name given for concrete that contains autonomous healing substances which can enter within the existing cracks and heal them without any human manual intervention. Autonomous healing is most frequently achieved by mixing concrete with fibers, crystalline admixtures, bacteria, polymers, and other smart materials. Normally, the chemical reactions and presence of water constitute the autonomous healing procedure that assesses the natural healing mechanisms. Therefore, the strength of the concrete is enhanced subsequent to the diminished width of the cracks via the autonomous healing procedure. Figure 1 portrays the autonomous procedures involved in the artificial autonomous healing. The efficacy of the self-healing mechanism is enhanced via the immobilization, vascular, or encapsulation techniques that incorporate healing agents into the concrete.

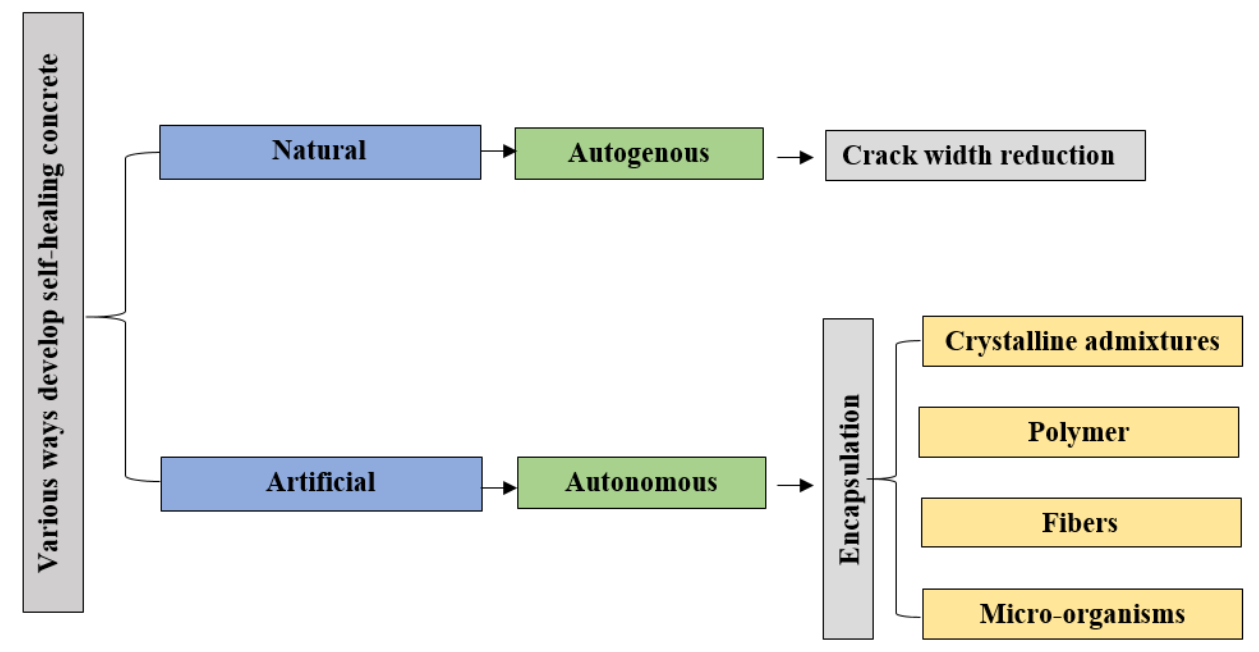

Figure 1. Development of methods for self-healing concrete production.

The self-repairing of damaged concrete surfaces using the bacteria-mediated biological processes has recently been proposed [12-16]. In the mid-1990s, Gollapudi [17] proposed a sustainable technique to heal concrete cracks wherein ureolytic bacteria was added in the concrete to accelerate the calcium carbonate $\left(\mathrm{CaCO}_{3}\right)$ precipitation within the existing micro-cracked regions. The bacteria strains in the concrete [18-21] were utilized to produce the urease enzyme for catalyzing urea $\left(\mathrm{CO}\left(\mathrm{NH}_{2}\right)_{2}\right)$ into ammonium ions $\left(\mathrm{NH}^{4+}\right)$ and carbonate $\left(\mathrm{CO}_{3}{ }^{2-}\right)$ radicals. The overall chemical reactions followed various pathways. Using the reaction Path I, urea of $1 \mathrm{~mol}$ was first subjected to the intracellular 
hydrolyses of carbonate $(1 \mathrm{~mol})$ and ammonia $(1 \mathrm{~mol})$. Next, following the reaction Path II, spontaneous hydrolysis of carbamate occurred to generate extra 1 mole of ammonia and carbonic acid. Later, these compounds produced bi-carbonate $\left(\mathrm{HCO}^{3-}\right)$ of $1 \mathrm{~mol}$ and ammonium $\left(\mathrm{NH}^{4+}\right)$ and hydroxide $\left(\mathrm{OH}^{-}\right)$each of 2 moles following the reaction Path III and IV. Following reaction Path IV and V, the mixture $\mathrm{pH}$ was enhanced, which could drift the equilibrium of bicarbonate, forming carbonate ions as described below.

$$
\begin{gathered}
\mathrm{CO}\left(\mathrm{NH}_{2}\right)_{2}+\mathrm{H}_{2} \mathrm{O} \rightarrow \mathrm{NH}_{2} \mathrm{COOH}+\mathrm{NH}_{3} \\
\mathrm{NH}_{2} \mathrm{COOH}+\mathrm{H}_{2} \mathrm{O} \rightarrow \mathrm{NH}_{3}+\mathrm{H}_{2} \mathrm{CO}_{3} \\
\mathrm{H}_{2} \mathrm{CO}_{3}+\mathrm{H}_{2} \mathrm{O} \rightarrow \mathrm{HCO}^{3-}+\mathrm{H}^{+} \\
2 \mathrm{NH}_{3}+2 \mathrm{H}_{2} \mathrm{O} \rightarrow 2 \mathrm{NH}^{4+}+2 \mathrm{OH}^{-} \\
\mathrm{HCO}^{3-}+\mathrm{H}^{+}+2 \mathrm{NH}^{4+}+2 \mathrm{OH}^{-} \rightarrow \mathrm{CO}_{3}^{2-}+ \\
2 \mathrm{NH}^{4+}+2 \mathrm{H}_{2} \mathrm{O}
\end{gathered}
$$

Path I

Path II

Path III

Path IV

Path V

The bacteria cell wall surface first attracted the cations from the neighboring environment due to the presence of negative charges in the cell walls, thus decomposing $\mathrm{Ca}^{2+}$ on the cell walls surface. Then, on the bacteria cell walls surface, $\mathrm{CaCO}_{3}$ was precipitated due to the chemicals' reactions amid $\mathrm{Ca}^{2+}$ and $\mathrm{CO}_{3}{ }^{2-}$ that offered the active sites for further nucleation and growth [18]. Figure 2 illustrates the self-repair mechanism of the cracks on the concrete surface due to the precipitation of $\mathrm{CaCO}_{3}$ via the immobilized bacteria.

$$
\begin{gathered}
\mathrm{Ca}^{2+}+\mathrm{Cell} \rightarrow \text { Cell-Ca }{ }^{2+} \\
\text { Cell- } \mathrm{Ca}^{2+}+\mathrm{CO}_{3}{ }^{2-} \rightarrow \text { Cell-CaCO} \\
\end{gathered}
$$

Path VI

Path VII
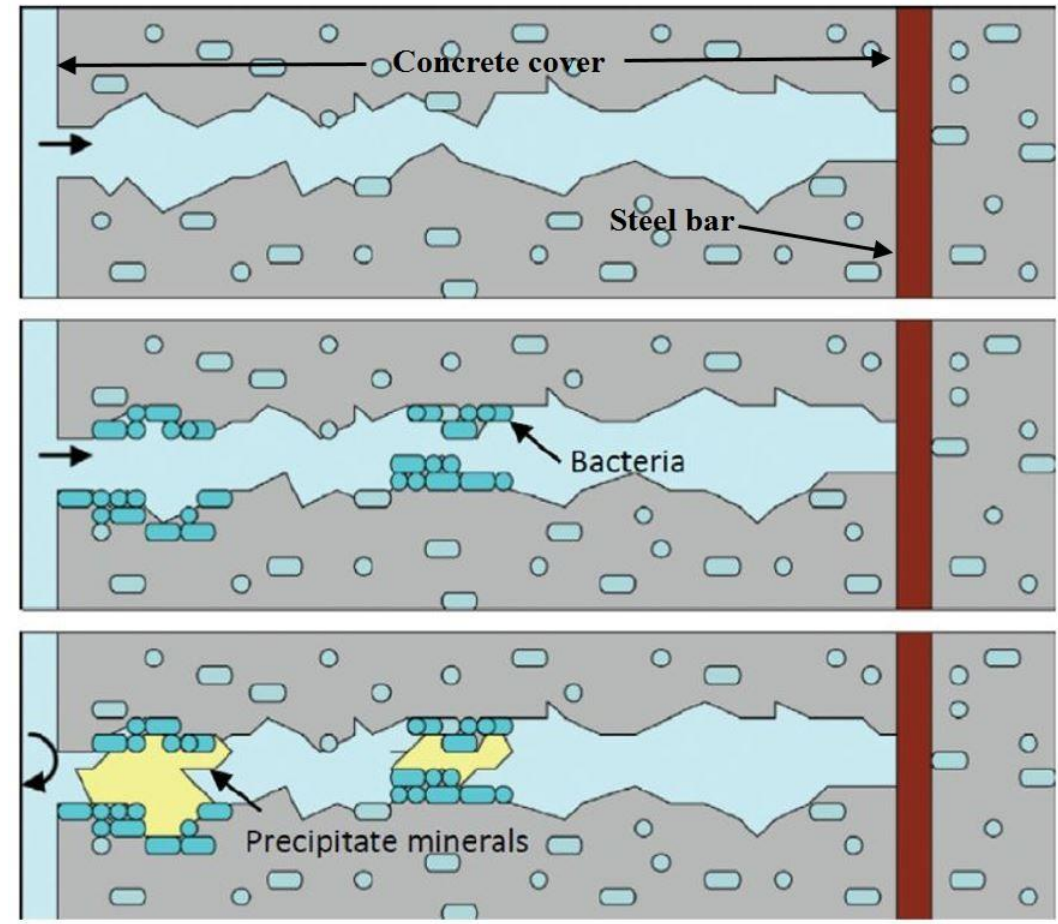

Figure 2. Classic crack-repair mechanisms in the concretes via the immobilized bacteria [12].

Considering the practical benefits and demands of the smart bio-agents-activated sustainable self-healing cementitious materials in the construction engineering sectors worldwide, this paper critically reviewed diverse approaches developed for producing functional self-healing smart materials. The advantages and limitations of various selfhealing techniques, mechanisms, design strategies, and measurement methods are extensively overviewed, compared, analyzed, and discussed. In addition, the effectiveness of the self-healing properties is determined by noting whether the cement-based material reflects its original form and functionality following the autonomous repair of the formed cracks. Finally, the economic and environmental benefits of the smart agents-based self-healing concretes and their prospects towards sustainable construction industry are emphasized. 


\section{Significance of Self-Healing Cementitious Materials}

Repetitive studies revealed that several load and non-load bearing elements can reduce the lifespan of concrete due to the degradation and formation of cracks in the concrete structures. The lifespan of concrete structures can be prolonged via the prevention and healing of such cracks together with the general maintenance activities. Nevertheless, the materials used for repair and anthropogenic activities can cause pollution, the repair sites may be impossible to reach, and the intensive labor, as well as high capital, are needed to carry out maintenance operations. The need for manual intervention can be diminished via the autonomous healing approaches. Much international academic attention has been placed upon specific approaches that offer an environmentally friendly solution to heal the formed cracks via the carbonate precipitation induced by smart biomaterials such as bacteria. Assessing the efficacy of self-healing of cracks in concrete following the incorporation of smart materials such as bacteria encapsulated in protective capsules or combined directly with the concrete is one of the novel technologies adopted to produce smart concrete. The mechanical performance, sealing capacity, and durability recovery of the smart materials are the key factors that ascertain the efficacy of the bacteria-assisted autonomous healing. Other factors responsible for the efficiency of bacteria-induced autonomous healing are the continued existence of the capsules throughout the admixing of concrete, smart bio-agents encapsulation and nature of materials in the capsules plus the impact of added capsules or bio-agents on concrete properties. Inspired by these aspects, the present communication explored various existing issues concerning the smart bio-agentsactivated sustainable self-healing cementitious materials and the need for future studies.

\section{Sustainability and Self-Healing Process of Cementitious Materials}

Concrete remains one of the most widely used construction materials due to its excellent strength performance and ease of use. However, generation of cracks in different types of concretes is unavoidable due to its weakness in the tension. As a result, the lifespan of concrete structures is often compromised because of the development of cracks and ingress of harmful substances through these cracks. Crack repair is generally laborious, time consuming and costly [19]. Conversely, the creation of self-healing concrete is an engineered approach that leads to an autonomous healing of the cracks when applied. Bacteria with calcium nutrient source are incorporated in the concrete to achieve autonomous healing of the cracks, wherein the calcium carbonate precipitates upon the formation of a crack, thus, filling the crack volume. It is known that the traditional concrete has less strength and durability than bacterial concrete. In this view, calcite precipitation into the formed cracks within concrete may be a basis of the biotechnological approach to enhance the durability and strength of the concrete structures [20,21].

Rebar corrosion, drying shrinkage, external loading, plastic shrinkage, thermal stress, or a combination of these factors can lead to the formation of cracks. For instance, shrinkage can cause micro-crack formations and the presence of an external mechanical load enables the cracks proliferation into a network at lower stress level. Chemical degradation of the concrete structures can occur when chemicals and moisture ingress into the concrete through such network of cracks. In addition, high levels of precipitation and moisture can aggravate such issues. Substantial costs, complicated accessibility, and the production of pollution are among the issues linked with manual interventions to repair the cracks in concrete. Currently, a range of cement-based and chemical repair materials are utilized to solve the cracks-related degradation of concrete structures. Environmental and health risks, as well as the material unsuitability, are associated with the use of chemical healing agents. Presently, about $7 \%$ of the anthropogenic $\mathrm{CO}_{2}$ emission worldwide is due to cement production [22-24]. Significant structural or durability problems frequently arise as microcracks go undetected when they form at the initial or later stages of construction. It has been realized that recurrent maintenance of the concrete structures can prevent this loss, yet it comes with a significant financial toll. Thus, making manual intervention obsolete via 
a sustainable cost-efficient method of repairing the formed cracks in the concrete structures became necessary.

Over the last decade, the utilization of the autonomous healing techniques in the building structures has drawn much acclaim owing to their capacity in repairing the deterioration within materials of high caliber. Additional economic and environmental benefits can occur when self-healing techniques are implemented to relieve the need for humanassisted maintenance operations. Thus, researchers have focused on the precipitation mechanism of calcium carbonate stimulated by the microbes as a sustainable scheme to stop the crack formations. Bacillus Subtilis is one such bacteria and an autonomously healing microbe that directly acts upon a calcium compound such as calcium lactate to facilitate the cracks filling in concrete via the precipitation of calcium carbonate [22]. Such precipitation also occurs through a ureolytic bacteria such as Bacillus Sphaericus, causing the decomposition of urea $[25,26]$. The setting of concrete occurs in an environmentally sustainable manner during the process of microbe-induced calcium carbonate precipitation in the cracked concrete structure [27]. Moreover, there is no health risk associated with the bacteria Bacillus Sphaericus [28]. The likelihood of reinforcement corrosion is further decreased as oxygen is consumed in the mentioned procedure. The bacteria species type Bacillus is discerned to be an optimal autonomous healing agent with the ability to form spores while being resistant to highly moist and alkaline environments. Thus, the most common bio-agent for the calcite precipitation in concrete is the Bacillus $[29,30]$.

\section{Self-Healing Techniques}

\subsection{Expansive Agents and Mineral Admixtures}

At the micro-scale, the self-healing concrete can repair the formed cracks, while restoring the mechanical properties of the cement-based materials. The generation of self-healing concrete, in line with the sustainable development, has involved multiple studies into the natural healing process via bacteria, alongside chemical and autogenous self-healing [31,32]. Furthermore, self-healing concrete can be improved through the integration of the microorganisms, hollow fibers, microencapsulation, polymers, mineral admixtures, and other expansive materials [31].

Additional hydration of the unreacted cement component, expansion of the hydrated cementitious network matrix, obstruction of the cracks with the impurities in water, and formation of $\mathrm{CaCO}_{3}$ are the mechanisms that can lead to the organic occurrence of the autonomous healing [33]. Moreover, the self-healing properties in concrete can be generated via the utilization of various geo-materials, polymers, and chemical admixtures [34]. Other form of self-healing properties in concrete can be achieved through the calcium carbonate precipitating microorganisms $[35,36]$. The ability of concrete to autonomously repair itself can be enhanced by the amalgamation of mineral admixtures and cementitious materials with expansive properties. Nevertheless, direct contact of cement with water must be prevented from prematurely expanding and thereafter degradation of concrete.

Cracks formed at the micro-scale can be filled via the calcium and magnesium silicates that dissolve in water, thus, making the pore solution of concrete [37]. However, these methods do not repair cracks in their entirety; rather, the plugging effect diminishes the size of the cracks. Through the tensile preloading, high-strength concrete is damaged; these simulate the crack formations, subsequently demonstrating the self-healing properties when exposed to water and moist environments [38]. The cementitious composites can be incorporated with the synthetic fibers to achieve complete healing of the simulated cracks [39]. The crack formations at the micro-scale have autonomously been repaired more efficiently via the use of supplementary cementitious materials (SCMs) [33]. Improved self-healing of the cracks in concrete and a reduction in the cement consumption are the primary benefits of these SCMs [40]. Additionally, high-performance fibers can be used to reinforce such cementitious composites [41]. 


\subsection{Polymers}

The aforementioned approaches outperform the self-healing action when they undergo distinct curing regimes wherein oily water, sea water, and water submersion constitute these regimes. An effective closing of the cracks only occurs when their sizes are below $50 \mu \mathrm{m}$, thus, demonstrating the limits of this form of autonomous healing. Rather than using still water, a constant water leakage has been used by researchers to heal the crack formations in concrete, demonstrating an enhanced autonomous healing effect [42]. Shrinkable polymers have been utilized to induce post-tensioning of concrete, which results in improved selfhealing efficacy [43]. Researchers have focused on the engineered cementitious composites, discovering their enhanced autonomous healing performance as a potential autonomous healing material [44]. Other studies found that, when the engineered cementitious composites are combined with the limestone powder, the functionality was almost entirely restored [45]. Further research was conducted on the carbonated steel slag to examine whether it can effectively act as a self-healing agent in concrete, wherein an optimum healed dimension of $20 \mu \mathrm{m}$ (wide) $\times 5 \mathrm{~mm}$ (long) was achieved using this method. The width of the filled crack was evaluated using diverse techniques such as X-ray computed tomography, light microscopy, ultrasound scanning, and camera photography [46,47].

Few studies were conducted to extend the service life and autonomous healing of the concrete structures via the integration of polymers into the concrete mix [48]. Encouraging findings were achieved through this method. Nonetheless, the polymer types determined the efficacy of the self-healing products [49]. Additionally, the efficacy of the autonomous healing process was dependent upon the water-to-cement ratio, type of cement, and polymer dosages. Enhanced autonomous healing was also induced via the amalgamation of separate materials with the polymer [48]. It was concluded that a complete restoration in the CS can possibly be achieved by certain polymer-based self-healing agents [50]. Almost two thirds of the formed crack width was filled through the autonomous healing catalyzed by a polymer [51]. High values of ultrasonic pulse velocity (UPV) and improved flexural strength (FS) restoration were obtained [52,53]. Additionally, performance of diverse methods for autonomously healing concrete were compared [54]. The method of utilizing a super-absorbent polymer was found to be better than the enacting encapsulation technique for the autonomously healing concrete. It is established that, because the autonomous healing can be induced without using water, the encapsulation techniques can be implemented in a greater range of applications.

\subsection{Nanomaterials}

It is possible to simulate the organic characteristics in the building materials using various nanomaterials that embody the cutting-edge technologies [55,56]. These characteristics can be generated in the novel materials produced via the combination of the nanoparticles into the concrete mixes [55]. Very high levels of chemical reactivity are produced in the novel material due to high surface area to volume ratio of the nanoparticles. Accordingly, novel smart materials with ideal properties can be produced at large scale needed for varied practical applications. Thus, the emergence of nanotechnology enabled the production of new and sustainable cementitious composites with outperforming attributes. The evolution of the self-healing concrete could advance through the use of functionalized silica nanoparticles, a material with great potential as highlighted by numerous researchers [57]. Hence, further investigations are required within this domain to reaffirm such a claim. The impact of different nanoparticles on the durability characteristics of various cement-based materials has been studied [58]. In addition, waterproof performance of concrete was improved using different nanocomposites [59].

\subsection{Bacteria}

In recent times, the study of bacteria-activated autonomously healing materials generated renewed interests $[24,60]$. Meanwhile, the generated cracks in concrete were efficiently filled using the mixed and isolated bacterial cultures [61]. It was argued that the metabolic 
activity of the bacteria can induce the calcium carbonate precipitation, thus, filling the cracks in concrete [62]. Autonomous healing can be catalyzed by the injection of a bacterial culture onto the concrete surface [35]. Additionally, in a parking garage, the bacterial cultures were sprayed directly on the concrete surface containing several cracks [63], wherein the autonomous healing was found to substantially decrease the water permeability into the cracks, thus, preventing further decay of concrete surface. Nonetheless, there was no substantial restoration of the CS. It has been reported that the CS and durability of the concrete and cement mortar could be improved through the microorganisms' incorporation [64]. The use of admixtures in concrete in combination with bacteria was shown to cause additional enhancement of the CS [65] up to 36\% [66]. Driven by these ideas, many studies have been conducted to explore concrete durability and strength enhancement via the incorporation of bacteria.

A distinct method of injection and spraying was enacted to place bacteria directly into the concrete mix, which led to the ureolytic activity and provoked microbial precipitation, thus, filling the formed cracks. Although this method outperformed many other techniques, the life span of bacteria was, however, shortened because the concrete matrix environment was intolerant for the bacteria. Consequently, the efficacy of autonomous healing was lowered with the passage of time [12]. The presence of nucleation sites, the concentration of the calcium ion, $\mathrm{pH}$, and concentration of dissolved inorganic carbon were the main reasons that led to the microbial precipitation. The added bacteria were substantially impacted by the high alkalinity in the concrete mix, making it a harsh habitat. It was concluded that the life span of bacteria can only be enhanced though their safeguarding [13]. The bacterial encapsulation was proposed to be an effective method for bacteria protection, which could improve the autonomous healing properties of the concrete mix. Through the use of polyurethane, a bacterial culture was immobilized in the concrete matrix. This, in turn, led to the gradual reduction of enzymatic activity and prolonged the bacteria lifespan [67]. In addition, the stability of the enzymatic activity was provoked for a prolonged time.

Immobilized bacteria in the concrete structures were found to cause about $60 \%$ restoration in the CS value [26]. To achieve this goal, the ureolytic bacteria was incorporated into the concrete matrix [68], leading to a gradual filling of the formed cracks via the calcium carbonate precipitation within the cracks. In addition, the performance of the immobilized bacteria became stronger with the passage of more time [69]. Concrete was combined with a hydrogel containing encapsulated bacterial spores and a crack measuring $0.5 \mathrm{~mm}$ wide was healed in its entirety, wherein nearly $70 \%$ decrease in the water absorption was observed [30]. It was also demonstrated that a crack width of almost $1 \mathrm{~mm}$ was c filled in its entirety via the improved performance of immobilized bacteria within the microcapsules [25]. Furthermore, the graphite nanoplatelets were used to encapsulate bacteria [21], wherein the formed crack at 7 and 3 days was plugged entirely when a crack of width $0.81 \mathrm{~mm}$ secreted a healing agent from the capsule after being stimulated by the crack formations. An achieved even distribution of nanoplatelets throughout the concrete matrix was beneficial for effective filling of the nanoscale cracks and enhancement of the CS by almost $10 \%$.

The conditions, including efficacy of the healing agents' in-situ rupture, processing survivability, and thermal stability, must be met by the encapsulated materials when used for the healing purposes. For the granules containing bacteria, the formation of a coating agent from geopolymer was shown to have a great potential [70]. Its implementation as an autonomous healing agent within concrete can achieve stellar results. Simultaneously, research was conducted on the potential autonomous healing agent of a double walled sodium silicate microcapsule [20]. A remarkable level of performance was shown by the mentioned microcapsule that efficiently activated an autonomous healing of the concrete cracks. It was asserted that the profundity of the generated crack filling served as a basis for the assessment of an autonomous healing potency [20], wherein the cracks with a depth of $27.2 \mathrm{~mm}$ and $32 \mathrm{~mm}$ were healed. The extended mechanical performance and life span of the encapsulated bacteria was found to improve the efficacy of self-healing 
of the concrete cracks much better than other techniques and approaches. Additionally, the bacteria encapsulation approach could plug larger crack formations in their entirety. Evolution of the autonomously healing concrete via the addition of chemical and biological agents proved to be a potential approach [71], which was verified by the complete filling of the generated cracks of $0.22 \mathrm{~mm}$ width.

\section{Self-Healing Mechanisms and Design Strategies}

It is well-known that human skin and tissues can repair themselves through the replacement of the damaged areas based on the nutrient uptake. Similarly, the essential products serve as nutrients in the cement-based materials with a self-repair capability, enabling these materials in repairing the damage or deterioration (Figure 3). Many studies have been performed in recent years to discover new methods for achieving an effective selfrepair material alongside the durability of the cement-based materials. Figure 4 illustrates an overview of such methods.

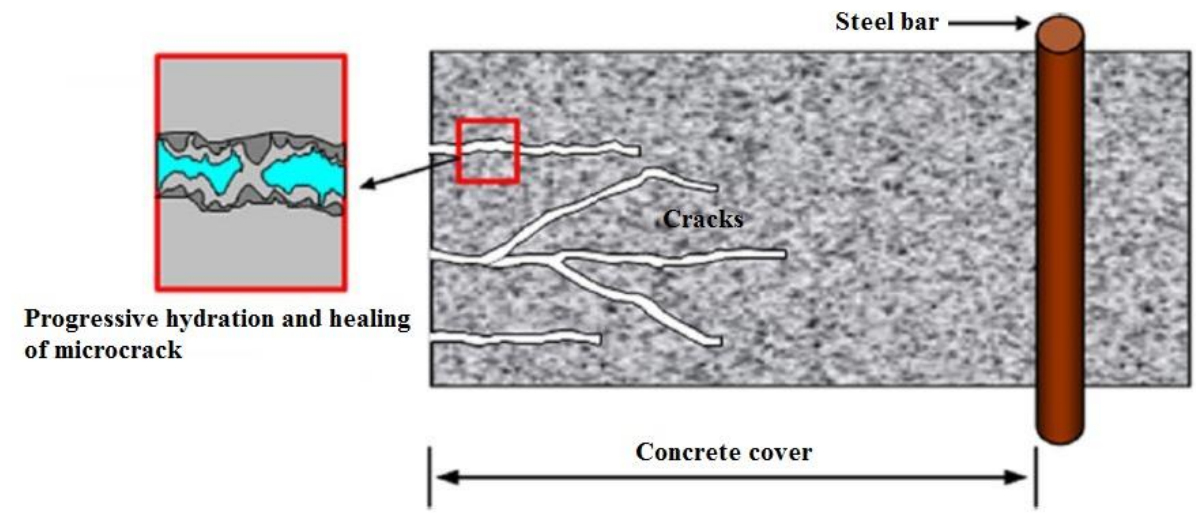

Figure 3. Healing process of micro-cracks in concrete cover because of unhydrated cement nucleiassisted continued hydration [12].

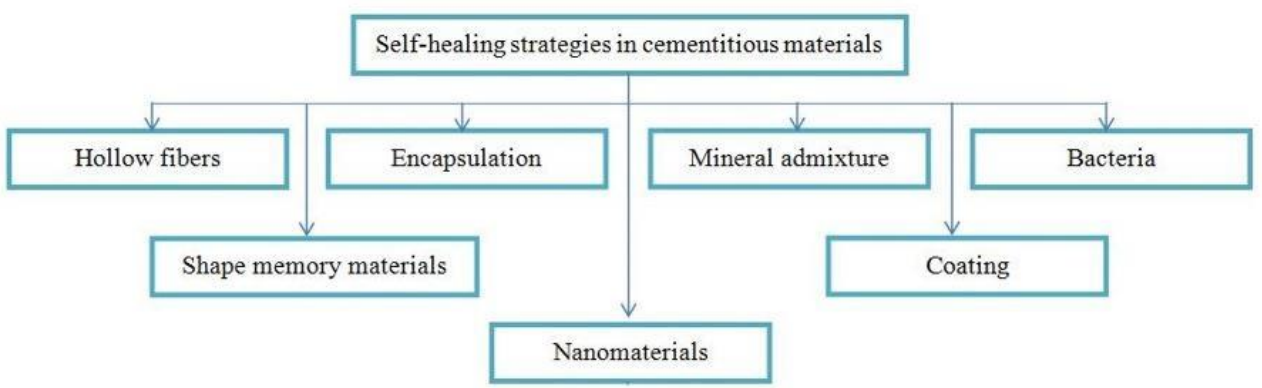

Figure 4. Various strategies for cement-based materials self-healing.

It is customary to discuss the self-healing mechanisms shown by varieties of materials, including plastics, polymers, paints, coatings, metals, alloys, ceramics, and concretes. These materials possessing their own self-healing traits are useful for the design strategies of the concrete mixes. The primary self-healing processes are the: (i) release of healing agent; (ii) reversibility of the cross-links; and (iii) miscellaneous technologies. Liquidactive self-healing agents, such as monomers, dyes, catalysts and hardeners enclosing the micro-capsules, hollow fibers, or channels, are usually added into the polymer system as reservoirs during their production. In the presence of cracks, these reservoirs are broken, thereby pouring the reactive agents into the cracks via the capillary forces; thereupon, they solidify due to the existence of pre-disposed catalysts, effectively healing the cracks. The cracks propagation is considered the main driving stimuli in the healing mechanism. Conversely, the stress needed from the cracks for relieving remains the main limitation of this automatic mechanism, which happens in the absence of any physical or exterior 
intervention. Various concepts, such as the embedment of (i) microcapsules, (ii) hollow fibers, and (iii) micro-vascular systems involved in designing the self-healing materials are explained hereunder.

Microencapsulation is a process of attaching micron-sized particles of solids, droplets of liquids, or gases in an inert shell, which in turn isolates and protects them from the external environments [72,73]. The end product of the microencapsulation process is termed as microcapsules. Generally, these microcapsules are spherical or irregular in shape with varying sizes in the range of few nanometers to micrometers. Various self-healing polymeric composites have been designed by incorporating different healing agents or catalysts enclosing microcapsules. It has been suggested [74] that the implementation of microcapsules-embedded healing agents in the polyester network matrix could yield excellent self-healing efficiency, however, not successful enough to produce self-healing components useful for practical purposes. White et al. [75] first demonstrated the possibility of getting practical self-repairing material, wherein the self-healing capabilities were achieved by embedding encapsulated healing agents into the polymer matrix containing dispersed catalysts. Figure 5 depicts the self-healing strategy via the microcapsules embedment.

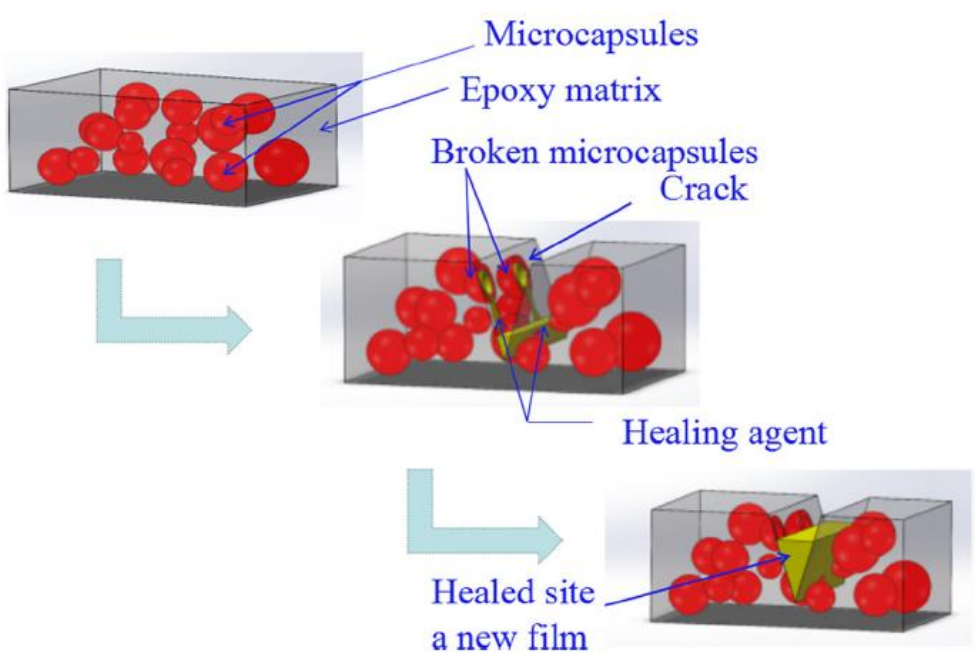

Figure 5. Schematic diagram representing the self-healing strategy via the microcapsules embedment [76].

There are many advantages to the microcapsule-based self-healing approach, but the uncertainty about how to achieve a complete and/or multiple healing agent limits their applications [77]. Multiple healing is only feasible when excess healing agent is available in the matrix after the first healing occurs. Thus, to achieve multiple healing in the composite materials, another type of reservoir that might be able to deliver larger amount of liquid healing agent was developed. However, such an approach has not received wide popularity due to limited success. Various composite systems formulated using the filled glass fibers have limitations. In fact, they could not set free the resin into the cracks because of high viscosity of epoxy resins and inadequate time of curing (Figure 6).

Therriault et al. [78] utilized other approaches comparable to the biological vascular systems (such as plants and animals) to surmount the problems related to inadequate delivery of the healing agents into the microcapsules-based components. They relied on central micro-vascular networks for the healing agents' dispersion into the polymer matrix via the continuous pathways. The synthesis procedure was complicated and extremely complex to accomplish the synthetic agents compatible to these networks for realistic applications. In this approach, organic ink was deposited using three-dimensional (3D) arrays and the interstitial porous spaces among the printed linings were infiltrated by the epoxy resin. Upon curing the polymers, the fugitive ink was eliminated, leaving behind a 3D micro-vascular channel with precise connectivity. Polymer-based materials with micro- 
vascular networks were made by adding chemical catalysts into the polymers, which were then infiltrated into the organic ink scaffolds. The healing agents were entered within the micro-vascular channels followed by the polymers curing and scaffolds removal. Several studies were carried out to fabricate such polymer-based self-healing materials and to evaluate their self-healing abilities [79].

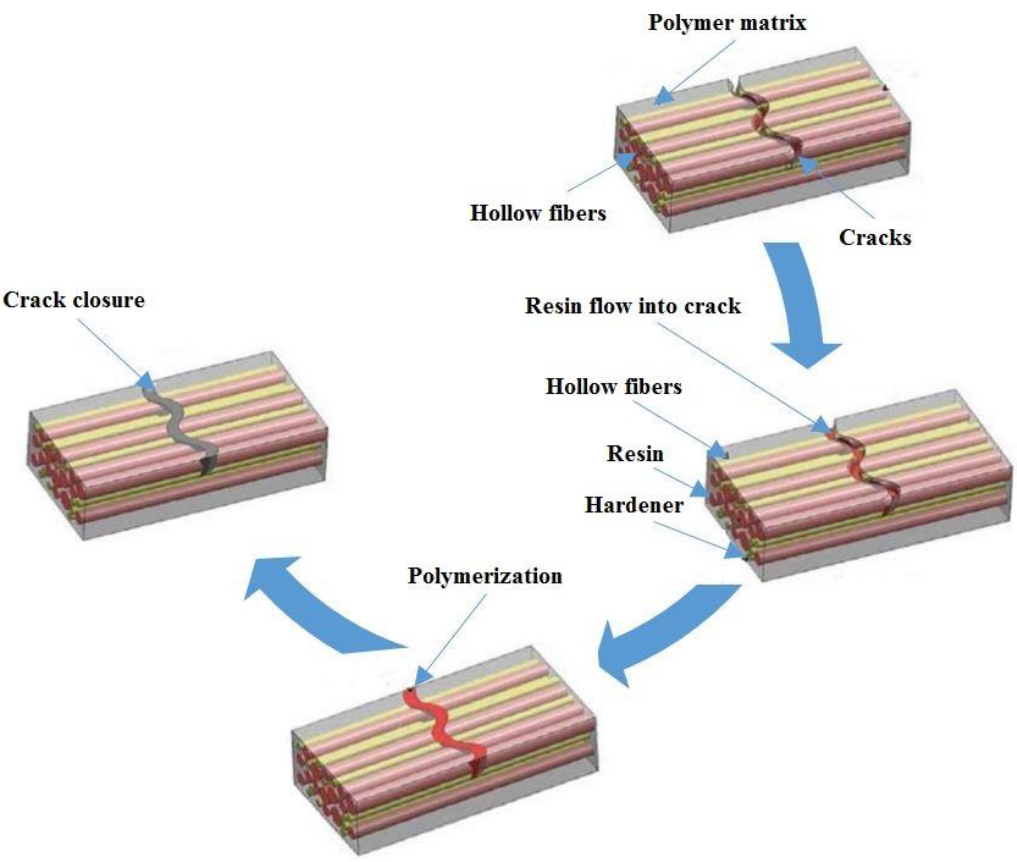

Figure 6. Schematic representation of self-healing concept using hollow fibers [12].

Being an irreversible process, the cross-linked polymer-based materials are designed to attain better mechanical performance, including large elastic modulus, high resistance against various solvents, and high fracture strengths. Conversely, the cross-linking in the polymeric system negatively impacts their reproduction capacity. On top, materials with a large number of cross-links are disadvantageous due to their brittleness and tendency to develop micro-cracks. To overcome this limitation, reversible cross-linking in polymerbased materials was introduced, leading to excellent processing capability. Reversible cross-linked polymeric materials show good self-healing traits together with re-fabrication and recyclable characteristics. Nevertheless, such materials are unable to reveal self-healing capacity independently. Some externally applied stimuli, such as chemical, thermal and optical excitations, are required to obtain the reversible effects of the self-repairing capability. In short, such materials display non-autonomic repairing behavior. Various techniques for evaluating the reversible cross-linking in polymeric system are described hereunder [79].

\section{Self-Healing Evaluation Techniques}

Several researchers assessed the widths of the plugged-in cracks, mainly using the microscopes [80,81]. Other techniques include the X-ray computed tomography, photographs from cameras with a very high pixel capacity, and digital images [82]. The occurrence of the natural phenomenon can plug-in a crack of maximum size $60 \mu \mathrm{m}$ (Table 1). Meanwhile, polymer was utilized to plug-in a crack of width $138 \mu \mathrm{m}$. In addition, crack of width $200 \mu \mathrm{m}$ was filled by inserting SCMs within the concrete mix. Upon preparing the concrete, the microorganisms' encapsulation technique was implemented to heal a large crack of width $970 \mu \mathrm{m}$, indicating progressive enhancement in the healing process. The profundity of the crack formation served as a basis for assessing the autonomous healing capacity [83]. Another study assessed the self-healing efficacy of the encapsulation technique using a formed crack. The encapsulation technique was utilized to plug-in a crack of maximum 
depth $32 \mathrm{~mm}$, while the microorganisms were used to plug-in a crack $27.2 \mathrm{~mm}$ deep. Table 2 shows that the encapsulation is the best approach, wherein the maximum depth and width of the plugged-in crack can be $32 \mathrm{~mm}$ and $0.97 \mathrm{~mm}$, respectively. Furthermore, a crack with a maximum length of $5 \mathrm{~mm}$ was filled-in [84].

Table 1. Techniques, approaches and measured variables of self-healing.

\begin{tabular}{ccc}
\hline & \multicolumn{2}{c}{ Techniques of Self-Healing Materials } \\
\hline No. & Approach & Depth of the crack \\
\hline 1 & Microencapsulation & Maximum depth of $32 \mathrm{~mm}$ \\
\hline 2 & Bacteria & Maximum depth of $27.2 \mathrm{~mm}$ \\
\hline No. & Approach and Measured Variables of Self-Healing \\
\hline 1 & Approach & Widths of the cracks \\
\hline 2 & Natural & Repairing of cracks under $60 \mu \mathrm{m}$ wide \\
\hline 3 & Auxiliary cementitious materials & Cracks of width less than $200 \mu \mathrm{m}$ \\
\hline 4 & Polymer and epoxy & Cracks of maximum width of $138 \mu \mathrm{m}$ \\
\hline
\end{tabular}

Table 2. Scale of structural tests adopted for the assessment of self-repairing efficacy.

\begin{tabular}{lll}
\hline No. & Scale & Tests \\
\hline 1 & Macrostructure & $\begin{array}{l}\text { UPV, CS, FS, toughness, stiffness, water absorption } \\
\text { (permeability), and chloride resistance or permeability. }\end{array}$ \\
\hline 2 & Microstructure & Water absorption. \\
\hline 3 & Microscopic assessment & Visual observation and FS. \\
\hline 4 & Nanostructure & FS, UPV and nanomechanical measurements. \\
\hline
\end{tabular}

\section{Efficacy of Autonomous Healing Techniques}

The efficacy of autonomous healing techniques was assessed using various techniques. It was demonstrated that diverse factors, such as age of the formed cracks, curing regimes, and widths of the cracks, can affect the autonomous healing process in the formed cracks in concrete [85]. Table 3 shows the findings from diverse studies that assessed independent, independent and control variables. It was asserted that an improved autonomous healing can be achieved with both immobilized and free organisms due to the increased precipitation of calcium carbonate stems from an elevated concentration of bacteria in the concrete mix (Table 3). Similarly, the polymer dosage increase can boost the self-healing capacity. Autonomous healing was found to improve due to the presence of magnesium in bulk water; within the natural self-healing process the calcium in bulk water had no positive effect. Various curing regimes of the engineered cementations concrete was found to improve the efficacy of water curing. Additionally, the addition of biological and chemical agents into the concrete mix one at a time was found to enhance the autonomous healing, wherein the improvement due to the former was better than the later. The sole utilization of microcapsules was also found to be less effective than bio-encapsulation. Autonomous healing was impacted less significantly by the moisture and air curing techniques, thereby highlighting the more effective water curing method as observed from the comparison of various curing regimes (Table 3). As a crack became increasingly wider, the efficacy of the autonomous healing was diminished. A crack of $0.81 \mathrm{~mm}$ wide was entirely filled, while an almost $10 \%$ increase in the CS was observed due to the implementation of nanomaterials [21]. 
Table 3. Control variables and methods for self-healing materials.

\begin{tabular}{llll}
\hline No. & Control Variables & Methods & Results \\
\hline 1 & Immobilized organism & Optical density & $\begin{array}{l}\text { Higher ureolitic activity with immobilized samples for } \\
\text { prolonged duration }\end{array}$ \\
\hline 2 & Laboratory condition & Optical density & More self-repairing at optimal contents \\
\hline 3 & Microfibers & Weight present & Completely plugged the cracks up to size of $138 \mu \mathrm{m}$ \\
\hline 4 & Medium cultures & Liner methods & $\begin{array}{l}\text { Mixed bacterial cultures could plug cracks without } \\
\text { appreciably regaining the CS }\end{array}$ \\
\hline 5 & Ambient conditions & Particle sizes analyses & Higher self-repairing with microcapsules of size 230 $\mu \mathrm{m}$ \\
\hline
\end{tabular}

\section{Structural Tests for Self-Repairing Efficacy Evaluation}

The hardened concrete and its quality were determined via the structure tests at the nano, micro-, and macro-scale, wherein the nanostructures, microstructures, and macrostructures were evaluated. Table 4 illustrates how these assessments could measure the efficacy of the autonomous healing. The cement-based material showed sufficient self-healing after cracking, meeting the required quality criteria and restoring its functionality. In addition, the macrostructures of the hardened concrete were evaluated to ascertain the autonomous healing effectiveness. In some studies, the dependability of the findings was improved via the microstructures assessment. Nonetheless, the autonomous healing efficiency of concrete at the nanostructures scale has rarely been explored.

Table 4. Structural analyses for self-repairing efficacy evaluation.

\begin{tabular}{lll}
\hline No. & Test & Dependent Variable. \\
\hline 1 & Strength properties & CS, FS and splitting TS. \\
\hline 2 & Permeability & UPV, chloride penetration, gas permeability. \\
\hline 3 & Scanning electronic microscopy (SEM). & Fabric of nanostructures of concrete. \\
\hline 4 & Nanostructures' measurements & Nanomechanical properties. \\
\hline
\end{tabular}

\subsection{Macrostructures Evaluation}

Multiple assessments at the macro-level were carried out to ascertain the self-healing effectiveness of concrete. The extent of flexural and CS, as well as other mechanical properties, recovery was tested and assessed (Table 2). Toughness and split TS assessments form a part of these tests [86-88]. Various studies reported that UPV and water permeability assessments form a part of these tests $[89,90]$. Encapsulated tetraethyl orthosilicate, colloidal silica, sodium silicate and their respective effectiveness in autonomously healing were evaluated using the gas permeability and sorptivity tests [91]. These assessments revealed about an $18 \%$ and $69 \%$ decrease in the sorptivity and gas permeability, respectively. The healed material's performance was measured using the stiffness test [92]. The control specimen was found to have 50\% less FS than the healed concrete [52]. In the crack sites, a white deposited material was identified, and thermo-gravimetric analysis was performed [48]. Table 2 shows the oxygen profile, chloride penetration depth, pore size distribution and porosity results obtained using different tests. Through the autonomous healing, up to $60 \%$ of the CS was recovered. Thus, the biological self-healing technique may be suitable for the durability criterion over a prolonged time, wherein the concrete infrastructures and their life span can be prolonged by such an approach. Nonetheless, some evaluations, such as permeability, stress-strain relationship, and bond strengths amid concrete and deposited agents in the formed cracks are seldom made. Hence, multiple techniques must be used to accurately assess the development of the autonomously healing concrete. In short, the suitability with the concrete composition and bonding ability of the deposited material in the formed cracks must be compared more effectively. 


\subsection{Microstructures}

Following the autonomous healing mechanism, the deposited material in the formed crack in concrete was analyzed and identified using different methods, enhancing the dependability of the findings. Techniques like X-ray diffraction (XRD), field emission scanning electron microscopy (FESEM), and scanning electron microscopy (SEM) were used. The deposited materials residing within the formed cracks were identified using SEM [93]. It was concluded that distinct bacterial strains, calcium carbonate precipitation, polymerized and hydration products made up these materials. Raman spectroscopy was used to evaluate the autonomous healing performance [10]. Table 2 presents the energy-dispersive $\mathrm{X}$-ray (EDS), XRD, and SEM findings. The dependability of utilizing bacteria as an autonomous healing agent was optimized via this method [60]. Additionally, the microstructures analyses revealed that the cracks in the test samples contained some deposits made of irregular crystals. Hence, while signal transmission rate of UPV was amplified, the acid ingress, chloride permeability, and water absorption dropped significantly

\subsection{Nanostructures Tests}

The dependability of the findings was optimized via diverse nanoscale assessments. Nanostructures were tested to assess the efficacy of the autonomous healing [94,95]. The results in Table 2 clearly demonstrated the existence of strong bonds between the deposited layer and concrete matrix, wherein the average values of nanomechanical parameters at the outer precipitates were $20 \%$ lower compared to the transition zone. The bonding strength between the cement-based material, or the substrate, and the deposited materials at the interface, was evaluated via the nano- and macro-level assessments, thus, enhancing the method's dependability.

\subsection{Comparison of Assessment Methods}

Multiple techniques were used for diverse assessments (Table 5). Measurement of the autonomous healing efficacy of a material through its macro-mechanical properties is the method adopted by most researchers. Moreover, this method is considered to be optimum because it focused on the macrostructure properties and durability, making the findings more dependable. To further improve the dependability of the findings, some studies carried out the durability tests followed by a microscopy to examine the widths of the formed crack. More dependable results were obtained by the microscopic observation in tandem with the microstructures assessment. To ascertain the self-healing effectiveness, macro- and microscopic mechanical tests were also performed by a few researchers (Table 2). Microand macro-structural assessments were conducted to determine the autonomous healing efficacy, wherein, sometimes, the former was performed in tandem with the durability tests. The sole use of durability tests to ascertain the autonomous healing efficacy was observed to be a less dependable method. Furthermore, two investigations were made for nano-level assessments to ascertain the autonomous healing efficacy (Table 2). A comprehensive overview of the literature indicated that the macro-mechanical and durability tests, nanostructure and microstructure assessments have never been utilized simultaneously. Increased dependability in determining the autonomous healing efficacy can be deduced in the future studies by forming an approach that integrates the abovementioned versatile techniques.

\section{Effect of Parameters on Performance of Cementitious Self-Healing Agents}

Autonomously healing concrete can be achieved via the crystalline admixtures. The hydrophilic properties of crystalline admixtures cause the water permeability of the concrete to decrease, while enhancing the mechanical properties. The corrosion of steel is overcome by the alkalinity and the stiffness of the concrete is enhanced due to the incorporation of the crystalline admixtures [96]. The permeability of the concrete is diminished due to the needle-shaped structures that arise from the crystalline admixture when it reacts with water, acting as a waterproofing layer that fills in the formed cracks. Thus, the capacity 
to turn concrete into a water barrier makes its use effective in water tanks, dams, and other hydraulic structures. Subsequent sections highlight various studies that combined concrete with crystalline admixtures to achieve improved traits effective for functional applications.

The influence of crystalline admixtures on the autonomously healed concrete has been reported [97], wherein the concrete specimen was subjected to various exposures and loading-induced pre-cracks. The propagation of the crack was halted through the use of steel fibers. The compressive and splitting tensile strengths were assessed. Standard concrete showed about $14 \%$ less CS than concrete with crystalline admixes. The values of CS and TS of the specimens were improved by $13.98 \%$ and $35 \%$, respectively, by incorporating calcium sulphate-hydrate and calcite (Table 5).

Table 5. Crystalline admixtures based self-healing cementitious materials.

\begin{tabular}{llll}
\hline Ref. & Exposure Condition & Crack Healing & Findings \\
\hline [97] & Immersion in water & 0.2 to $0.4 \mathrm{~mm}$ & Enhancement in CS and TS by 13.98\% and 35\%, respectively. \\
\hline [98] & Immersion in water & $0.86 \mathrm{~mm}$ & $\begin{array}{l}\text { Concretes with CA revealed the maximum self-repairing } \\
\text { rates, for the cracks of larger widths up to } 0.25 \mathrm{~mm} .\end{array}$ \\
\hline [99] & Immersion in water & $0.4 \mathrm{~mm}$ & $\begin{array}{l}\text { For cracks up to } 0.40 \mathrm{~mm} \text {, the corresponding ratio of healing } \\
\text { and closing was } 0.99 \text { and } 0.98 \text { after } 42 \text { days. }\end{array}$ \\
\hline
\end{tabular}

The compatibility of crystalline admixtures as a healing agent in the autonomously healing concrete was examined [98], in which distinct environmental conditions were used for the crystalline admixtures and fiber-reinforced concrete mixes. The healing performance was measured via the optical microscopy and permeability assessment. The crack width was remarkably reduced due to the immersion in water. The self-healing efficacy of the concrete mixed with crystalline admixtures was also examined [99]. The efficacy of the autonomous healing property was evaluated via the crack closing and permeability assessments, wherein two mixes were prepared one with $275 \mathrm{~kg} / \mathrm{m}^{3}$ of cement and waterto-cement ratio $(\mathrm{w} / \mathrm{c})$ of 0.60 and another with $350 \mathrm{~kg} / \mathrm{m}^{3}$ cement and $\mathrm{w} / \mathrm{c}$ ratio of 0.45 . The CS of standard concrete was found to be $15 \%$ lower than precast concrete that contained crystalline admixtures. Improved healing was demonstrated at $30^{\circ} \mathrm{C}$ when the samples were immersed in water followed by the incorporation of crystalline admixtures.

The cracks formation in the autonomously healing mortar surface via the expansive crystalline additives (CEA) in the concrete were investigated [100]. The healing process was enhanced by placing the pre-cracked samples in water for 28 days where the surface cracks widths were approximately $100-400 \mathrm{~mm}$. The surface cracks were found to fill due to the incorporation of CEA. The crystalline admixture and calcium sulfo-aluminate content was $1.5 \%$ and $10 \%$ of the cement weight, respectively. The large surface crack of $400 \mathrm{~mm}$ was healed in its entirety by such autonomous healing substances. Moreover, in 28 days, an absolute drop in the healing occurred because of water penetration. It was concluded that a substantial enhancement in crack closing capability can be triggered by the incorporation of calcium sulfo-aluminate and crystalline admixtures. The calcium carbonate precipitation was crucial and was positively affected by the quantity of calcium precipitated from the concrete mix. In addition, conventional concrete was observed to release significantly fewer calcium ions than concrete incorporated with CEA. The autonomous healing performance of concrete mixed with crystalline additives was examined [96,101] to determine the nature of the healing rate and its impact under accelerated and natural curing conditions. The natural environment conditions were created by immersing the samples in water and air. Furthermore, the air chambers were among the accelerated environment conditions applied on the undamaged and pre-cracked beams for the flexural strength assessment. The widths of the formed pre-cracks in the samples were $270 \mathrm{~mm}$ and $130 \mathrm{~mm}$, which were created both with and without additives.

Generally, the binding of monomers via long chains leads to the formation of the polymers. A polymer net layer that heals the cracks is made after the polymer binds 
with cement particles once they are incorporated into the concrete. The higher viscosity of the polymers enables them to fill the cracks efficiently. The effects of polymers as the autonomous healing agents in concrete have been intensively studied. For example, pellets filled with healing gel and made with polymers were incorporated into concrete to test their healing efficacy [102]. The encapsulation method was used to incorporate the polyurethane capsules into the cracks to fill them using the healing agent. The mechanical properties of the concrete sample were assessed via split tensile and three-point bending tests. An increase in the spit tensile and FS were observed in the samples after curing for a week. The super-absorbent polymers and polyurethane were combined and used as healing agents [54]. The concrete containing acrylate and acrylamide superabsorbent polymer (SAP) was mixed with polyurethane fibers. The CS of the standard concrete was found to be $18 \%$ higher than that those made using super-absorbents, thereby demonstrating that the observed improved strength was not an outcome of the polyurethane mixing. When subjected to flexural testing, the crack width in the concrete became $250 \mathrm{~mm}$. The hydration process triggered the generation of calcium carbonate, wherein the swelling of the super-absorbent polymers was catalyzed via the released water inside the formed cracks. Thus, the calcium carbonate healed the cracks by filling them.

A study was conducted to determine the influence of acrylate-end capped polymer precursors for healing the cracks in concrete [103]. This was induced via the entry of capsules into the concrete containing epoxy acrylate and polyester acrylate-like chemicals. Elongation caused the damage in the polymer walls when subjected to a load, which was due to the mixing of the concrete specimens with the polyester-based substances and propylene glycol. When the specimen was placed in an alkaline environment, such polymers still do not deteriorate because of their strong self-recovery capacity. The polyester-based healing agent strain limit was below $50 \%$ and the width of the formed crack was increased above $50 \%$. The restriction of cement particles and PPG binding was observed via the visual test. In short, the potential of acrylate polymers as healing agents is significant and the type of acrylate-capped precursors determines the self-recovery procedure.

Various healing adhesives contained within the microcapsules and mixed with cementitious materials is an upcoming research area [86]. The autonomous healing ability can be generated by combining the cement paste with the polystyrene-divinylbenzene (stn-DVB), diglycidyl ether of biphenyl and epoxy resin (E), and other similar types of adhesive materials. Parameters involving strength can substantially be enhanced via this mix. Table 6 shows that the FS and CS of normal concrete were 1.3 times and 1.9 times weaker, respectively, than that of the autonomously healing concrete. The efficacy of the superabsorbent polymers as self-recovery agents was examined [104] and ascertained via a water flow test. When exposed to water, the superabsorbent polymer showed an expansive trait and functioned as a cross-linked polymer. The widths of large cracks were significantly reduced through the self-healing procedure. The FS of the control concrete was $8 \%$ weaker compared to the self-healing concrete (Table 6). In addition, the autonomous healing capabilities of the cementitious composite materials were investigated [105], wherein the reaction rate was found to improve via the accelerator microencapsulating triethyl borane and methyl methacrylate monomers. A comprehensive mixing of the solution containing the microcapsules and methyl methacrylate occurred within the concrete. Three kinds of carbon microfiber-reinforced mortars were designed, and their mechanical performance was assessed. The first served as the control sample, the second was the sulfonated polystyrene modified mortars, and the third one was the autonomously healing mortar. The polymers-based self-healing cementitious materials designed using the encapsulation method showed significant improvement (Table 6) in their strength properties (CS, FS and TS). The strength of the healed crack in the concrete was examined after incorporating the flexible polymers as healing agents [106], wherein the encapsulation method enabled the incorporation of polymers into the concrete (Table 6). The TS of the autonomously healing concrete was evaluated using the split tensile tests, wherein the specimen was cured for 
3 days at $20^{\circ} \mathrm{C}$. The $\mathrm{FS}$ of the concrete was found to improve by $35 \%$ after the healing of the crack by the flexible polymers.

Table 6. Polymers based self-healing cementitious materials.

\begin{tabular}{|c|c|c|c|}
\hline Ref. & Method & Test & Major Findings \\
\hline [102] & Encapsulation & $\begin{array}{l}\text { Three-point bending and } \\
\text { splitting TS }\end{array}$ & $\begin{array}{l}\text { FS and TS values were increased from } 52 \text { to } 62 \% \text { and } 40 \text { to } \\
64 \% \text {, respectively when polyurethane was incorporated into } \\
\text { the tubes. }\end{array}$ \\
\hline [54] & Vascular & CS & $\begin{array}{l}\text { For SAPs, the CS was reduced to } 18 \% \text { and cracks of width } \\
\text { up to } 50 \text { to } 250 \mathrm{~mm} \text { were healed due to swelling of SAPs. }\end{array}$ \\
\hline [86] & Encapsulation & CS and FS & $\begin{array}{l}\text { The CS and FS values were } 1.9 \text { and } 1.3 \text { times higher than the } \\
\text { normal concrete, respectively. }\end{array}$ \\
\hline [106] & Encapsulation & Three-point bending & FS was increased by $35 \%$. \\
\hline [49] & Direct & $\begin{array}{l}\text { Ultrasonic pulse } \\
\text { Velocity (UPV). }\end{array}$ & $\begin{array}{l}\text { The healing rates were appreciably increased depending on } \\
\text { the polymers' dosages. The repairing efficacy depended on } \\
\text { the age of the damages in both mixes designed without or } \\
\text { with polymers. }\end{array}$ \\
\hline
\end{tabular}

In a study, the concrete specimens were pre-cracked with the cracks' widths in the range of 100 to $400 \mu \mathrm{m}$ with the incorporation of SAP to determine the healing efficiency [107]. Specimens made with SAP showed $85 \%$ lower water flow than the normal concrete. In addition, a substantial reduction in the water flow was experienced by other mortars compared to the standard concrete. With regard to the cracks healing performance, the SAP was better than poly-acrylate. The results in Table 7 show more effective healing of the formed cracks in the concrete structures when the SAP particles were bigger. Various doses of the acrylic polymers and styrene-butadiene rubbers were mixed into the autonomously healing concrete [49]. The hydration process and healing time were evaluated via the thermogravimetric and UPV measurements. After nearly 3 weeks of curing, the rate of cracks healing was reduced. This was mainly due to the presence of styrene rubber in the concrete, wherein the cement particles were bonded with the polymer, indicating that the polymer dosage determined the healing time. Furthermore, the incorporation of styrene-butadiene rubber caused a reduction in the hydration process, while the healing time was prolonged by the polymer content.

Table 7. Obtained CS values of different kind of bacteria.

\begin{tabular}{lll}
\hline Bacteria Used & Best Results & Bacterial Concentration \\
\hline Bacillus sp. CT-5 & CS vale was $40 \%$ above the control specimen & $5 \times 10^{7} \mathrm{cells} / \mathrm{mm}^{3}$ \\
\hline Bacillus megaterium & $\begin{array}{l}\text { Maximum rate of strength development was } 24 \%(50 \mathrm{MPa}) \\
\text { showed by highest grade concrete. }\end{array}$ & $30 \times 10^{5} \mathrm{cfu} / \mathrm{mL}$ \\
\hline Bacillus subtilis & $\begin{array}{l}\text { CS was increased by } 12 \% \text { higher than control sample } \\
\text { containing LWAs. }\end{array}$ & $2.8 \times 10^{8} \mathrm{cells} / \mathrm{m}$ \\
\hline Bacillus aerius & $\begin{array}{l}\text { CS was increased by } 11.8 \% \text { in bacteria-added concrete than } \\
\text { control sample made with } 10 \% \text { rice husk ash. }\end{array}$ & $10^{5} \mathrm{cells} / \mathrm{mL}$ \\
\hline Sporosarcina pasteurii & CS was 35\% more than the control specimen & $10^{5}$ cells $/ \mathrm{mL}$ \\
\hline
\end{tabular}

Most common kinds of fibers are the man-made and natural ones. The former is known as synthetic fibers, industrially fabricated, and include polyvinyl alcohol, polypropylene, vinyl alcohol, polyester, and polyethylene. Drying shrinkage and plastic induced cracks in concretes are regulated and prevented via the incorporation of synthetic fibers, which also enhance the toughness and TS of the concrete. Water penetration through pores is safeguarded as fibers enable to decrease the permeability of the concrete mix. Enhancements 
in the mechanical properties of the concrete occur because of the fiber's incorporation. The cracks filling efficacy of various types of fibers as healing agents within concrete has widely been explored. The ability of the fiber-reinforced cementitious materials to seal the formed cracks was examined in detail [108]. Steel fibers, wollastonite, antifoaming agents, silica fume cement, and super-plasticizer were among the materials used in this study. When immersed in water, numerous cracks formed in the close proximity within the concrete were more effectively healed by the proposed materials. Surface cracks were examined via the microscopy and air permeability measurement. The autonomous healing procedure commenced with the immersion in water of the pre-cracked specimens. A decrease in the air permeability was observed while the cracks were filled by the precipitated crystalline particles emerged from the fiber-reinforced cementitious materials. The results indicated that the un-cracked samples had reduced air permeability compared to the cracked samples.

Multiple synthetic fibers were utilized to ascertain the healing performance of the fiberreinforced cementitious concrete (FRCC) [109]. Several distinct fibers such as polypropylene, ethylene-vinyl alcohol, poly-vinyl alcohol, and polyacetal were used. The primary materials consisted of polycarboxylic acid (super-plasticizer), silica fume, cement, and sand. The particles' diameters for cement-polypropylene (C-PP) and polypropylene (PP), polyvinyl alcohol (PVA)-I and II, ethylene vinyl alcohol (EVOH), and polyacetal (POM) were $18 \mathrm{~mm}, 11 \mathrm{~mm}, 37 \mathrm{~mm}, 14 \mathrm{~mm}, 15 \mathrm{~mm}$, and $48 \mathrm{~mm}$, respectively. The microscopic and air permeability of the samples were measured. The results revealed that the precipitates near the fibers led to a reduction in the water permeability. With PVA incorporation, a higher rate of calcium carbonate precipitation was observed in the high polarity of the fiber composites for cracks of width up to $0.3 \mathrm{~mm}$. A reduction in the water permeability was found in the PVA II-included samples, while healing occurred within $72 \mathrm{~h}$ for the PVA-included specimen.

Under cryogenic temperatures, the autonomous healing capacity of the fiber-reinforced concrete examined [110]. The samples were first cured in water for 28 days at $20{ }^{\circ} \mathrm{C}$ and then cured again under air exposure for 3 days at room temperature. A week was needed to seal the cracks of widths in the range of 10 and $50 \mu \mathrm{m}$ for the pre-cracked samples cured for 28 days. The sealing of the cracks of widths up to $50 \mu \mathrm{m}$ was achieved when the samples were subjected to $24 \mathrm{~h}$ of cryogenic temperatures. The FS properties of the specimen were affected by the fibers' lengths, wherein shorter fibers showed weaker FS. Three days of air cured specimen under cryogenic temperatures showed an improved FS wherein the pre-cracked samples were made with steel fibers with an aspect ratio of 97.5. The pre-cracked samples containing steel fiber (with an aspect ratio of 100) revealed weakest energy absorption capability. Some studies were performed to determine the effects of cellulose fibers mixing into concrete on the water permeability and autonomous healing efficacy [14]. The autonomous healing rate of the specimen was estimated via the water penetrability measurement and other tests. Concrete specimen prepared with $0.5 \%$ of cellulose fibers showed a decrease in the CS value. Contrastingly, the FS of the standard concrete was found to be $7.84 \%$ lower than that of the specimens made with fibers.

The effects of microfibers and SAP inclusion in concrete on the autonomous healing mechanisms were examined [48], wherein the cracks' sealing ability was improved via the incorporation of SAP. Upon exposure to a wet environment, SAP was swelled. When subjected to the wet and dry cycles, a crack of size $138 \mu \mathrm{m}$ was healed when $1 \%$ of SAP was included in the specimen. In addition, the SAP inclusion into the concrete was responsible for the cracks' healing and water permeability reduction. The feasibility of enhancing the autonomous healing capacity of cracks through the incorporation of diverse bacteria and fibers in the concrete were studied [111]. A decrease in the concentration and growth of the bacteria was observed, while the cracks with a width up to $500 \mu \mathrm{m}$ were successfully sealed. Following one week of curing, the pre-cracked control samples without bacteria or fiber demonstrated about 30\% healing, which was further improved by $2 \%$ after 28 days of curing. Following 28 days of curing, the control sample demonstrated higher crack repair ratio than those designed with PP1 (polypropylene) fiber. After 28 days of curing, 
a crack healing ratio of $31 \%$ was achieved in the sample designed with PP2 fiber. In the first week of curing, an improvement in the crack healing ratio of $36 \%$ was observed. The incorporation of only PP1 and PP2 fibers into the mortar produced weaker effects than the mortar prepared with polyvinyl alcohol (PVA) fiber. The crack healing ratio of mortars containing PVA fibers after curing for 7 and 28 days was enhanced from $44 \%$ to $50 \%$, respectively. Enhanced healing rates were observed when microscopic organisms such as bacteria were mixed in the mortar. Samples containing only fiber displayed lower healing rates than those made with fiber and bacteria. Concrete with these fiber and bacteria mixes showed reduced water absorption and improved FS.

Many investigations have been conducted to determine the effects of fibers, polymers, and diverse crystalline materials incorporation into concrete on the autonomously healing efficiency of cracks. The mechanical properties of autonomously healing concrete were measured using the split tensile, water tightness, flexural, permeability test, and CS tests. Elemental compositions and microstructures were analyzed using EDS and SEM measurements. Diminished water permeability was achieved via the surface layer cracks in the concrete when sealed after the reactions. Despite enough air exposure, such samples could seal the cracks by absorbing the moisture from the environment because of the hydrophilic properties of the admixtures. Furthermore, an enhanced crack sealing capacity was developed when the cracks were exposed to water [97]. Upon water exposure, such hydrophilic products melted and re-crystallized within the formed cracks due to the presence of crystalline admixtures. The internal cracks of the sample were plugged-in as calcium carbonate was produced and the supply of $\mathrm{Ca}^{2+}$ was facilitated by the incorporation of the expansive additives and crystalline admixtures into the concrete. Exposure to a humid environment could also enhance the precipitation of calcium because the additives mixed into the concrete had higher $\mathrm{pH}$ [100]. The incorporation of multiple polymer precursors into the concrete could facilitate the sealing of the generated larger and wider cracks in the sample. The mechanical properties of the concrete were enhanced due to the superior binding of mortar and polymers facilitated by the elastic properties of polyurethane [106].

The effects of microcapsules (containing triethylborane and methyl methacrylate monomer) insertion as healing agents into the concrete and their ability to heal cracks were studied [20]. After 28 days of curing, the value of CS of the concrete was increased up to $45.8 \%$. As a result of swelling, the polymer particles become larger, leading to a reduction in the micro-cracks within the concrete due the presence of SAP. A high $\mathrm{pH}$ environment in the concrete caused the reduced swelling of the SAP [104]. The cellulose fibers-assisted autonomous healing mechanism on cracks in the concrete was examined [112]. A reduction in the CS value of the concrete occurred due to the use of cellulose fibers. The mix ratio, cracked surface, roughness, and interaction of the fibers with the concrete were among the influential factors that were found to be responsible for effective healing [109]. Autonomous healing capability of cracks were improved in the ultra-high performance hybrid fiber-reinforced (UHFR) cementitious concrete [108]. The incorporation of bacteria and polypropylene into concrete was found to be less effective than PVA-based concrete in terms of healing efficacy [111]. The sealing of crack width was enhanced through the incorporation of micro-fibers and SPA into the concrete [48]. The autonomous healing capability and flexural performance of the concrete were also enhanced upon the incorporation of steel fibers into the concrete when subjected cryogenic temperatures [110].

\section{Bacteria-Activated Self-Healing Cementitious Materials}

Using bacteria that triggers the calcite precipitation to autonomously heal the cracks in concrete larger than $0.8 \mathrm{~mm}[85,113]$. It was noticed that the bacteria-based mortar suffers from a decreasing strength when fine aggregates are replaced by the lightweight aggregates. Standard lightweight mortars had less strength than bacterial lightweight mortars, demonstrating the latter's utility in lightweight structures. Durability and healing efficacy of a structure can be enhanced by the lightweight aggregates incorporation that are ideal vehicles for bacteria $[114,115]$. Some studies revealed that, irrespective of age, 
calcite precipitation can lead to significant improvements in the concrete strength when bacteria are combined with the rice husk ash-based concrete [116,117]. When calcium carbonate precipitation reached at the highest level, concrete shown an improvement in the strength properties up to $24 \%$ [118]. The permeability and porosity were decreased, and the strength was improved, when Sporoscarcina Pasteurii bacteria was incorporated into the fly ash (FA)-based concretes. Standard concrete experienced four times less water absorption than the mentioned mix, wherein the CS of the FA-included concrete was improved up to $22 \%$ [119]. In the initial stages of the crack formation, the mentioned autonomous healing technique could fill-in the crack, demonstrating its potential [120]. In brief, it was demonstrated that the autonomous healing approaches using vascular systems, capsules, and hydro gel encapsulation are effective in triggering the calcite precipitation in the concrete specimens and, thus, are capable of self-healing the concrete cracks.

\subsection{Self-Healing Approach}

The secretion of the healing agents can be triggered after occurrence of a crack or damage within an optimal autonomously healing system. The restoration of the microcracks in a concrete can potentially be handled by the autonomous healing techniques. Recently, the cracks located on the concrete's surface have been efficiently manage with the autonomous healing approaches. After the incorporation of bacteria, calcium carbonate precipitates were molded into the earlier cracks' layer inside the concrete [12,27]. Resistance to alkali environments is a required characteristic of the incorporated bacteria in the concrete structures [121,122]. The binding of the gravel and sand in concrete is facilitated by the microbiological induction of calcium carbonate precipitation that also aids the plugging-in of the formed micro-cracks [123].

The durability of concrete can be enhanced by incorporating various microorganismsmediated calcite precipitations reactions. Within a highly alkaline environment, Bacillus Sphaericus can precipitate calcium carbonate in concrete via the conversion of urea into carbonate and ammonium [13]. Thus, such concrete is capable of self-healing the cracks that are below $0.2 \mathrm{~mm}$ in size. The entrance of deleterious materials is not halted when the sizes of the cracks surpass $0.2 \mathrm{~mm}$ because the self-healing actions are not sufficient. The hibernation stage of the bacteria within the concrete is disrupted upon the appearance of cracks in autonomously healing concrete. The cracks are filled via the autonomous healing as the calcium carbonate precipitates into them due to the metabolic activities of bacteria. The hibernation stage recommenced once the calcium carbonate sealed the formed cracks entirely. Therefore, any new cracks can be filled due to the activation of the bacteria. Microbiologically-induced calcium carbonate precipitation (MCIP) is a mechanism that describes the nature of bacteria as a long-term healing agent.

The results in Table 8 indicate that the metabolic pathways of multiple bacteria determine the formation of calcium carbonate. Autotrophic processes are said to generate less precipitated calcium carbonate than heterotrophic processes. The requirement of organic carbon sources for the growth is characteristic of heterotrophs that are incapable of using carbon to make their own organic compounds. Conversely, simple substances are used to generate the complex organic compounds, such as chemosynthesis and photosynthesis, for autotroph organisms. The bacterial cells are protected by a mineral layer when the calcium carbonate is generated by the microbial [124,125].

Urealysis can generate $\mathrm{CaCO}_{3}$ precipitate; multiple microorganisms can be used to achieve the autonomous self-healing. A comprehensive literature review revealed the specific implementations of various types of bacteria in concrete as self-healing agents. Graphite nanoplatelets together with lightweight aggregates in concrete can improve the strength after Bacillus Subtilis are added [21]. Improvement in the concrete's durability was observed when rice husk ash concrete was incorporated with Bacillus Aerius bacteria [117]. The value of CS was increased by 25\% when Bacillus Megaterium bacteria was incorporated into the concrete [118]. Additionally, the durability of the concrete was enhanced due to the inclusion of Bacillus Sphaericus into the concrete that produced 
$\mathrm{CaCO}_{3}$ precipitates [47]. Following the autonomous healing, both durability and mechanical strength of the Sporoscarcina Pasteurii bacteria-incorporated FA-based concrete was improved [119]. Similarly, the same bacteria revealed comparable effects when added to silica fume concrete [119]. Another option for the surface treatment monitoring of the concrete was discovered via the introduction of Bacillus Sphaericus into it [126].

Table 8. Various metabolic pathways for the precipitation of bacterial $\mathrm{CaCO}_{3}$.

\begin{tabular}{|c|c|c|c|c|c|}
\hline Autotrophic Bacteria & \multicolumn{5}{|c|}{ Heterotrophic Bacteria } \\
\hline \multirow[t]{2}{*}{$\begin{array}{c}\text { Non-methylotrophic } \\
\text { methanogenesis }\end{array}$} & $\begin{array}{l}\text { Assimilatory } \\
\text { pathways }\end{array}$ & \multicolumn{4}{|c|}{ Dissimilatory pathways } \\
\hline & Urea decomposition & \multicolumn{4}{|c|}{ Organic carbon oxidation } \\
\hline \multirow[t]{2}{*}{$\begin{array}{c}\text { Anoxygenic } \\
\text { photosynthesis }\end{array}$} & & \multicolumn{2}{|c|}{ Aerobic } & \multicolumn{2}{|c|}{ Anaerobic } \\
\hline & & \multicolumn{2}{|c|}{ Processes/e-acceptors } & \multicolumn{2}{|c|}{ Processes/e-acceptors } \\
\hline \multirow[t]{2}{*}{$\begin{array}{c}\text { Oxygenic } \\
\text { photosynthesis }\end{array}$} & $\begin{array}{l}\text { Ammonification of } \\
\text { amino acids }\end{array}$ & Respiration & $\mathrm{O}_{2}$ & NOx reduction & $\mathrm{NO}_{3} / \mathrm{NO}_{2}$ \\
\hline & & Methane oxidation & $\mathrm{CH}_{4} / \mathrm{O}_{2}$ & Sulphate reduction & $\mathrm{SO}_{4}^{2}$ \\
\hline
\end{tabular}

Recent studies hinted that the encapsulation and direct application are the two principal approaches for applying the healing agent into the concrete. These approaches for incorporating the healing agents into the concrete include graphite nanoplatelets (GNP), addition of bacterial strains in the lightweight aggregate (LWA) and direct methods. The first method was found to produce the best outcomes in terms of autonomously healing of cracks, demonstrating the potency of GNP as a vehicle for the bacteria delivery into the concrete [21]. The best concentration of bacteria was found to be $30 \times 10^{5}$ colony forming unit (cfu)/mL after determining the said quantity and resultant strength using direct method for applying the healing agents [118]. Furthermore, the general autonomous healing performance of the concrete was enhanced through different method that involved the encapsulation in a polymer-based coating layer after the lightweight aggregates were impregnated by a bacteria solution [126].

Figure 7a displays the autonomous healing of materials via the microencapsulation approach. Capillary movement was utilized by the healing agent as secreted into the crack site following the rupture of the embedded microcapsules. The cracks formed in the close proximity were also self-repaired and polymerized as the embedded catalyst acted with the healing agent. Figure $7 \mathrm{~b}$ shows a standard broken microcapsule [127]. Quicker detection and reactions to a crack in the concrete matrix plus the ability to self-heal more kinds of cracks demonstrated the proficient autonomous healing of the encapsulation method [128]. In terms of the autonomous healing of the cracks and the quantity of precipitation in hydrogel-encapsulated bacterial spores, the efficacy of the self-healing was enhanced via the hydrogel encapsulation method [47]. The CS of the cement mortar was increased by $25 \%$ and maintained over a month when the Shewanella bacteria was added to the concrete via the direct method [64]. The safeguarding of the bacteria in the highly alkaline environment together with uniform distribution enables the encapsulation method to more effectively produce $\mathrm{CaCO}_{3}$ precipitation, thus, filling more cracks.

\subsection{Effect of Bacteria on Concrete Performance}

Table 7 shows the variation in the CS values, bacterial concentrations, and bacterial strains when different types of calcium sources are given to the bacteria. The calcium source supplied to the bacteria indeed determined rapidity or slowness of the setting times of the concrete upon the incorporation of the bacteria spore powder. The nutrients, such as calcium formate, calcium nitrate, and calcium lactate, were provided to the bacteria. The setting time of concrete was improved upon adding the calcium nitrate and calcium 
formate, while it was slowed down due to the addition of calcium lactate [113,129]. Calcite precipitation served as the basis for a biotechnological approach to enhance the strength of the concrete structures. Due to the permeability of the cement mortar, the initial curing period was highly nourishing for the microbial cells acclimatizing to a novel environment. During the curing period, the high $\mathrm{pH}$ level of the cement helped the bacterial cells to grow gradually. Multiple ions located in the media led to form the calcite precipitates in the cement mortar matrix and surface of the cell, while the cells continued to grow. Consequently, the cement mortar experienced a reduction in the permeability and porosity. The simultaneous filling of multiple pores in the matrix led to the halting of the flow of oxygen and nutrients into the bacterial cells, causing endospores or death of these cells. This clearly explicated the interaction of the microbial cells to enhance the CS of the mortar [130]. Lower grade concrete achieved less strength than higher grade concrete, as the calcite precipitation was greater in the latter after the addition of Bacillus Megaterium bacteria at the concentration of $30 \times 10^{5} \mathrm{cfu} / \mathrm{mL}$.

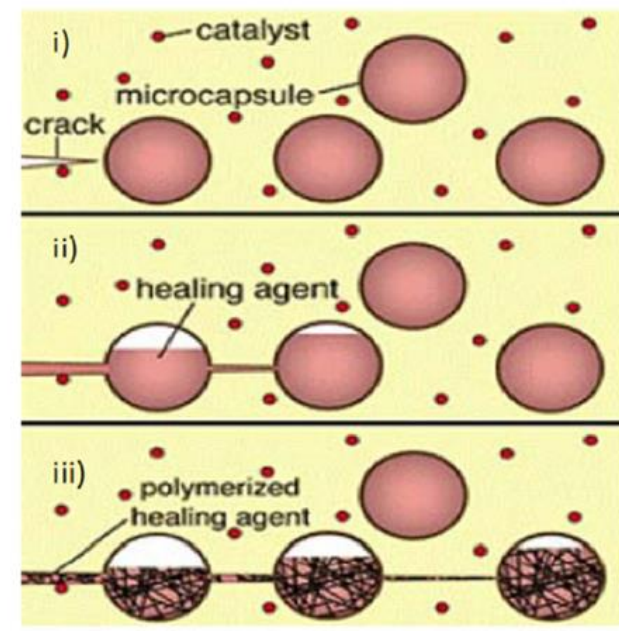

(a)

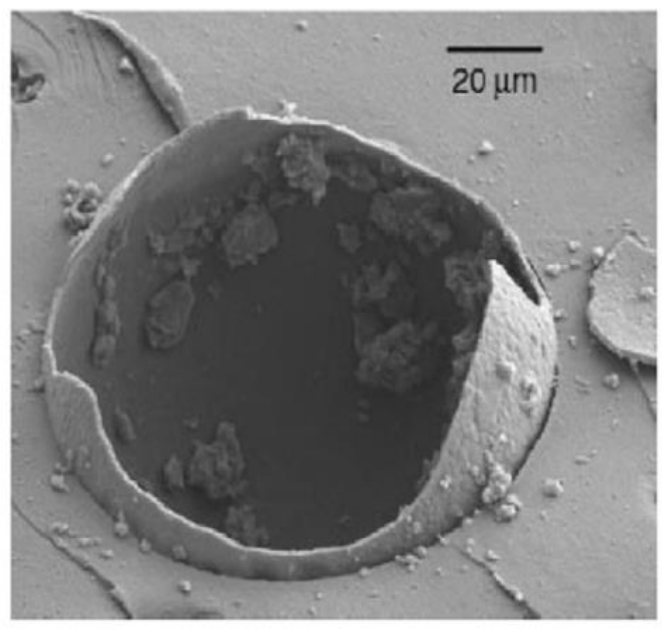

(b)

Figure 7. (a) Encapsulate self-healing mechanism and (b) SEM image of ruptured microcapsule [19].

In another study, the highest-grade concrete showed an increase in the strength by almost $50 \mathrm{MPa}$, indicating the possibility of the highest rate of strength development in such concrete [118]. Sparcious Pasteurii bacteria of concentration $10^{5}$ cells $/ \mathrm{mL}$ were included in FA-based concrete by substituting $10 \%$ of cement. The microorganism cell surface that was covered by the deposition of $\mathrm{CaCO}_{3}$ led to an improvement of the concrete's structural strength by $20 \%$ [119]. Additionally, the $\mathrm{CaCO}_{3}$ precipitation was responsible for the enhancement in the CS value of the silica fume-added concrete following the incorporation of the bacteria. The SEM and XRD microstructure analysis revealed the presence of calcium carbonate in the concrete matrix [131]. Over a period of 28 days curing, concrete prepared without Sparcina Pasteurii bacteria was found to have $20 \%$ less CS than the one designed with the bacteria [132]. Compared to the control specimen, the CS of the mortar containing bacterial cells was increased by 10,14, and $19 \%$ with the substitution of cement by fly ash (FA) contents of 40,20, and 10\%, respectively [65]. Optimal efficacy in the cracks self-healing was due to the presence of GNP that served as an ideal carrier compound for the uniform distribution of bacteria in the concrete matrix. Irrespective of age, the microbial precipitation of the calcium carbonate enabled an improvement in the CS value of the concrete when GNP was incorporated in tandem with the Bacillus subtilis bacteria [21]. The addition of reactive spore powder within the cement mortar caused a notable improvement in the CS value compared to the control specimen after 28 days of curing [113]. Bacillus sp. CT-5 led to the enhancement of the value of CS, as the pores 
of the mortar and cement-sand matrix were filled by the $\mathrm{CaCO}_{3}$ deposits on the cell's surface $[66,133]$.

The core property that reflects the concrete's durability is the permeability, because it regulates the entrance of the deleterious materials into the concrete, causing deterioration under a pressure gradient. In addition, the micro-cracks formation, tortuosity, connectivity, porosity, and size distribution are the main characteristics of the pore network within cementitious materials that affect permeability. The invasion of deleterious substances, the particle size distribution, the ratio of water to cement $(\mathrm{w} / \mathrm{c})$ and the age of hardened cementitious materials regulated the mentioned features [134]. Concrete specimens experienced a reduction in the permeability and water absorption due to $\mathrm{CaCO}_{3}$ deposition on the concrete. Likewise, a reduction in the permeability and porosity of the FA-based concrete occurred following the incorporation of S. Pasteurii bacteria [119]. Additionally, at the bacteria concentration of $10^{5}$ cells $/ \mathrm{mL}$, the concrete revealed a fourfold decrease in the water absorption [131]. Compared to the control specimen, the microbial calcite deposition led to a three times lower water absorption capacity of the concrete designed with Bacillus Megaterium and its nutrients [65]. It was concluded that the durability of the structural concrete can be enhanced via the calcite precipitation triggered by the incorporation of Bacillus Aerius, leading to decreased porosity and water absorption [121]. Pores plugged-in with calcium carbonate resulted in high to low permeability in AKKR5 bacteria-activated concrete at $10^{5}$ cells $/ \mathrm{mL}$ concentration, while a high to moderate permeability was shown by all the control cement bag house filtered dust concrete mixes at 28 days of age [135]. The water absorption of the recycled aggregates was decreased following the microbial precipitation, leading to an enhancement in their caliber $[136,137]$.

The degradation of the concrete structures occurs most frequently via the chloride ingress, which corrodes the reinforcing steel. The internal pore structures of concrete determine the rate of chloride ingress into the material. The factors such as construction practices, level of hydration, mix design, use of supplementary cementitious materials, and curing conditions determine the pore structures in the concrete matrix. Supervision of a sample for checking the amount of electrical current that passes through it is the method suitable for the rapid chloride permeability test. The permeability of a given kind of concrete receives a qualitative rating depending on the total charge that passes through the sample. The addition of bacteria in the concrete can decrease the chances of chloride permeation into it. Concrete devoid of bacteria was found to contain, on average, $11.7 \%$ more Coulomb than concrete containing bacteria. The mass reduction of sulfate exposed concrete was also found to be enhanced in addition to the decrease in chloride ingress in concrete when Bacillus Subtilis and Sparcious Pasteurii were incorporated into the mix [132]. The charge that passed through the rice husk ash (RHA) and control concrete samples was decreased due to the inclusion of Bacillus Aerius bacteria in the concrete. The lowest charge passed at all curing ages was demonstrated by the bacterial concrete. In comparison with standard concrete aged for 7,28 , and 56 days, the bacterial concrete samples experienced a 55.8, 49.9, and $48.4 \%$ reduction in the total charge passed through them, respectively [135]. Rapid chloride penetration of 380 Coulomb was resisted effectively when $10 \%$ of the silica fume concrete was combined with the best bacterial concentration of Sparcious Pasteurii [131]. Despite a mere 762 Coulomb penetration for the concrete containing $30 \%$ of FA, a drastic decrease in the chloride ions was found in every FA-based concrete when Sporoscarcina Pasteurii bacteria of concentration $10^{5}$ cells $/ \mathrm{mL}$ was added. It was concluded that the capability of concrete to repel the penetration of the chloride ions determines the lifespan of the concrete structures that interact with the de-icing salts or marine environments.

The SEM analysis revealed the existence of calcite precipitation in the concrete and mortar, wherein rod-shaped bacteria were found to be linked-in with the calcite crystals. The ingress of the deleterious substances was blocked by the deposits that served as an obstacle, resulting in a reduction in the permeability of the concrete [65]. Mineral precipitation led to the enhancement of the concrete's microstructure due the incorporation 
of bacteria, which was confirmed using the XRD, EDS, and SEM analysis. Compared to the concrete devoid of bacteria, concrete with different volumes of added bacteria achieved a maximum weight of calcium formation of $38.76 \%$ when the Bacillus Megaterium concentration was $30 \times 10^{5} \mathrm{cfu} / \mathrm{mL}$ [118]. Bacteria embedded with distinct and diverse calcite crystals were identified and visualized by the SEM analysis. XRD and EDS analysis verified the presence of high quantities of calcium in the specimen, where the calcite existed as $\mathrm{CaCO}_{3}$. Consequently, the durability of the concrete was enhanced $[137,138]$.

Figure 8 displays the SEM micrographs of the bacteria-activated specimen and control sample, wherein the calcite crystals were found to exist within the bacterial concrete [131]. It also affirmed the filling of the pores by the deposition of calcium carbonate due to the incorporation of bacteria in RHA concrete, indicating an enhanced strength of the concrete. Clearly, calcite was plugged in the voids of the bacterial concrete [135]. Microstructures analyses verified that the formed cracks in the test samples contained the calcium carbonate deposits. Hence, acid ingress, chloride permeability, and water absorption were diminished together with the increase of the UPV readings [139].

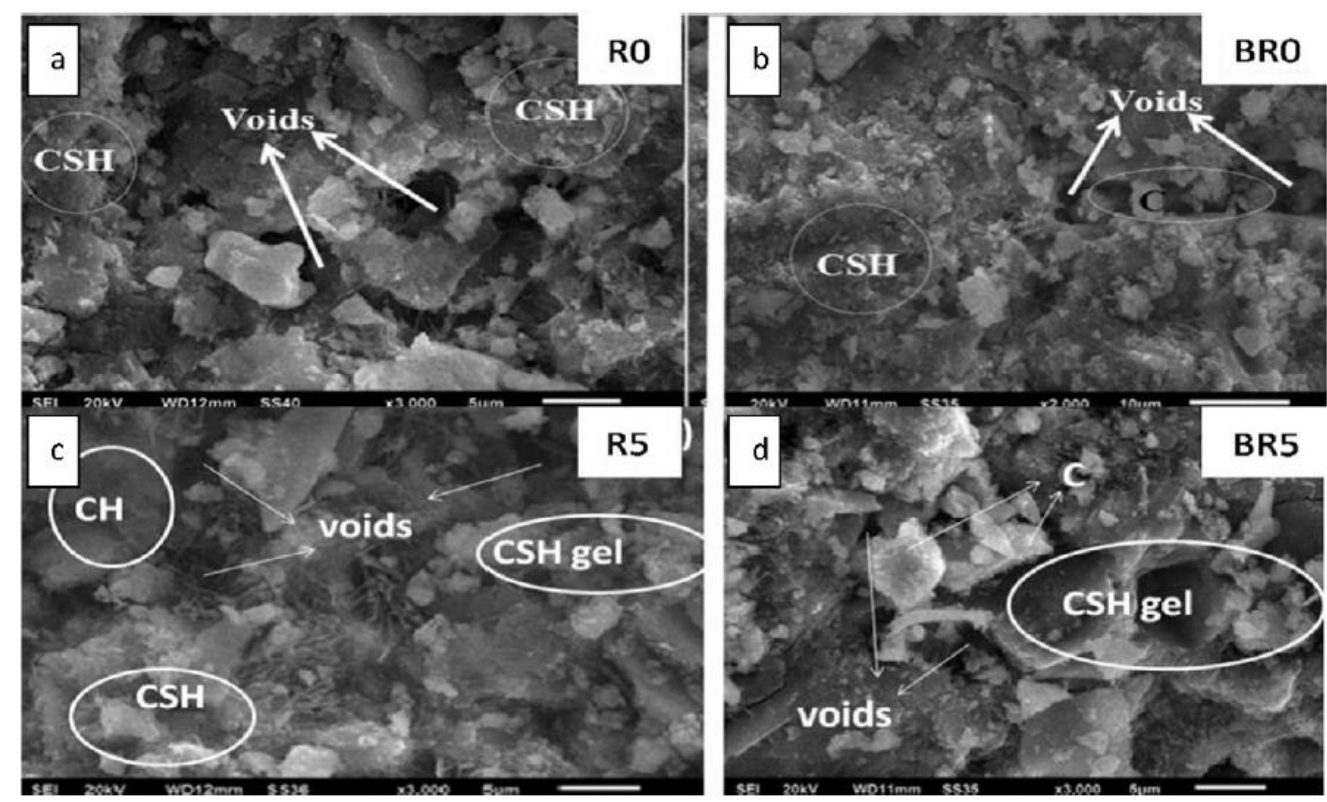

Figure 8. SEM micrographs of (a) normal concrete (R0), (b) bacteria-activated concrete (BR0) (c) 5\% of RHA concrete (R5) and (d) bacteria-activated concrete with 5\% of RHA (BR5) [19].

\section{Self-Healing Cementitious Materials Obtained Using Encapsulation Technology}

In optimal circumstances in a natural environment, the availability of nucleation sites, solution $\mathrm{pH}$, calcium ions concentration, and dissolved inorganic carbon concentration can appreciably influence the precipitation of calcium carbonate in the concrete [140]. The first of these aspects is delivered by the bacterial cell while the other three are linked to the concrete matrix. Hydrolysis of urea by bacterial metabolism or the conversion of calcium compounds such as Ca-lactate are the means through which bacterial precipitation can be achieved. The first method involves the hydrolysis of urea into carbonate and ammonium that triggers the calcium carbonate precipitation. The enzyme urease, which is produced by the Bacillus Sphaericus bacteria, functions as a catalyst during the hydrolysis. The generated carbonate reacts with the calcium ions extracted from the calcium nitrate or other calcium sources by the negatively charged bacterial cell, resulting in the calcium carbonate precipitation. The second method involves the production of carbon dioxide and calcium carbonate after calcium lactate reacts with the oxygen that enters into the concrete via the crack formations on the surface [140]. The produced additional calcium carbonate can be used for autonomous healing via the reaction of carbon dioxide with any portlandite particles in the close proximity. Non-hydrated calcium hydroxide particles can 
still be present in the freshly prepared concrete, enabling this method is more effective in such context.

It has been established that the efficacy of autonomous healing in concrete can be achieved using various methods, wherein the long lifespan of the bacteria, the depth or widths of the cracks to be repaired, moisture content, and the age of the concrete are the main governing factors. Improvement of the autonomously healing capacity in concrete was performed through the introduction of bacteria spores of different kinds to deduce their compatibility [141]. Bacillus pseudofirmus, Bacillus halodurans, and Bacillus cohnii were mixed in the cement stone-chips to improve its autonomous healing capacity. The tensile and CS of the cement stone-chips were assessed after they were cured in a peptonebased medium and yeast extract, wherein the bacteria-incorporated specimen revealed a significant improvement in strength properties compared to the control sample. Following 12 days of incubation, calcium carbonate crystals were precipitated as shown by the SEM image analysis. Nonetheless, the germination occurred after the specimens were cured in the medium enriched of organic carbon sources that were externally sourced.

More recently, the potential impacts of the mineral precursor compounds, peptone, and yeast extract on the autonomous healing capacity in concrete were examined [8]. The highly alkaline environment of the concrete is the principal difficulty that the bacteria must overcome to survive and, thereby, commence autonomous healing. The direct additions of different kinds to achieve bacteria-induced carbonate precipitation in the concrete for autonomous healing of cracks demonstrated their enormous potential [12]. Bacillus cohnii and Bacillus pseudofirmus were found to species of spores that form alkaliphilic bacteria. The mineral precursor compound was selected by assessing the calcium lactate and calcium acetate level. A marginal improvement in the strength occurred via the calcium lactate inclusion, while the calcium acetate produced high strength. Specimen cured for 28 days did not shown any precipitates on them, while the sample cured for 7 days revealed the deposition of calcium carbonate crystals in the size range of $20-80 \mathrm{~mm}$. Concrete with the decreasing pore size in highly alkaline environments showed a reduction in the number of suitable bacteria spores [85]. The deterioration of the concrete matrix was due to nitric acid generation from increased metabolic activity or reinforcement of the corrosion via the excess ammonia production that occurred in the urease-based method, demonstrating the superiority of the aforementioned technique for autonomous healing of cracks.

The direct incorporation of the substrate and alkali resistant spores in the concrete enabled the formation of bacteria which was further influenced by the cracks' ages and widths as well as the curing conditions. Concrete containing various ages $(90,60,28,14$, and 7 days) of cracks in the size range of 0.1 and $0.5 \mathrm{~mm}$ was subjected to the wet-dry cycles at $25^{\circ} \mathrm{C}$, water curing, and wet curing conditions to determine their effects on the autonomous healing process. The repair rates of such diverse cracks were assessed to ascertain the healing performance. The results revealed that roughly $85 \%$ of the generated cracks of widths $0.1-0.3 \mathrm{~mm}$ were filled and repaired entirely when subjected to the water curing condition. While the wet-dry cycle condition demonstrated a slower rate of healing; however, the condition of water curing was found to produce the best healing results. Older cracks were not healed as effectively as new or young cracks. The shorter transport distance of the mineral emerged from the reduction of the concrete porosity could partially explain this observation, while the lack of a protective shell for the bacteria might have caused a low survival rate [85].

The binding of the original concrete matrix with mineral precipitates is a key area to investigate in addition to their autonomous healing efficacy. The binding of the precipitated calcium carbonate with the parent concrete network, as well the nanomechanical properties of the former, were determined using a non-indentation technique, wherein a non-ureolytic bacteria was added within the mixing water that revealed the mechanical performance of autonomously healing concrete [94]. The creation of cracks led to the addition of air pockets for bacteria survival and a decrease in the alkalinity of the cement paste. However, the addition of air entraining agents, silica fume, and basalt fibers sustained the integrity of the 
specimens, thus, demonstrating an outperforming nature of this technique. Given that the durability and mechanical properties of concrete can be impacted by air voids in the tropics, this method may not be as suitable as in temperate climates where the dangers of thawing and freezing are reduced by such air voids. Nonetheless, in the case of fire, the release of vapor pressure is enabled by these voids, thereby enhancing the concrete's resistance to fire. The mineral precursor compound was filled by calcium glutamate and calcium lactate, wherein calcium lactate produced a less substantial conversion of calcium ion to carbonate than calcium glutamate. The latter (calcium lactate) formed granular-shaped crystals, which were totally absent in the former. Nevertheless, while thicker and denser carbonate from the glutamate was found in the transition zone, the biding of the carbonates made from the lactate and glutamate were found to vary insignificantly. Calcium glutamate specimens were observed to demonstrate a greater capacity in restoring the FS. Bacterial metabolism triggered the mineral precipitation that filled a part of the cracks of width between $0.1 \mathrm{~mm}$ and $0.4 \mathrm{~mm}$. The efficacy of the external healing was not surpassed by the samples incorporated with bacterial spores, yet the latter did exceed the healing performance of the control specimen. The limited amount of nutrients was responsible for this action, thereby impacting the performance of the bacteria, despite the voids aiding the bacteria.

The production costs of the cultures, such as the axenic spores of bacteria, are substantial, which is the major limitation of this approach, despite its promising results regarding the effective self-healing. The microbial community named cyclic enriched ureolytic powder (CERUP) was aimed to address this issue by offering a cheaper bioagent alternative [142]. Reduced production costs were achieved by making the specimen in non-sterile conditions while using a sub-stream of a vegetable plant as the microbial source. During a period of 4 weeks, the capacity to plug-in the cracks and autonomous healing was assessed via the incorporation of non-autoclaved and autoclaved CERUP. The width of the largest crack that was repaired by the autoclaved CERUP was below $0.37 \mathrm{~mm}$, while the width of the largest crack healed by the non-autoclaved CERUP was $0.45 \mathrm{~mm}$. A more accurate representation of the autonomous healing capacity of the non-sterile agent is essential, wherein additional evaluations regarding the durability and strength are necessary to ascertain its proficiencies besides significantly lower costs and deficiencies.

Autonomous healing that occurs during the entire lifespan of a concrete structure indicates the substantial effectiveness of the self-healing technique in filling the cracks indefinitely. Thus, a critical aspect is the survivability of the bacteria wherein multiple obstacles hindering the survivability of bacteria can appear upon the direct addition of bio-agents to the concrete. Relatively young specimens were found to be the only kind that achieved efficient autonomous healing, as the unprotected spores had a lifespan of two months [143]. The hydration of cement, mixing of concrete and alkalinity of the cement matrix were the main factors that contributed to the lifespan shortening. Residing in a highly alkaline environment for a prolonged period of time could significantly reduce the activity of spores. Additionally, the impact of aggregates, along with the mixing force, could lead to spores being damaged in the mixing stage. Despite the average size of bacteria cells being above $0.5 \mathrm{~mm}$, a reduction in the pore size of the matrix and porosity was triggered by the hydration of cement up to $0.5 \mathrm{~mm}$ [25]. It was concluded that, at an advanced stage, a concrete structure can experience a significant or even absolute decrease in the germination of cells due to the shrinkage of pores. The bacteria-induced carbonate precipitation and concrete properties were not impacted when the bacteria were encapsulated, thereby working around the mentioned limitation. The developed techniques to safeguard the bacterial strains include the hydrogels encapsulation, diatomaceous earth, melamine-based microcapsules, polyurethane and silica gel in glass tubes, and expanded clay aggregate encapsulation $[139,144]$.

Bacillus Sphaericus spores were encapsulated via the melamine-based microcapsules [25]. The nutrients, such as urea and yeast extract, were mixed along with the mineral precursor calcium nitrate in the concrete to obtain efficient autonomous healing of cracks. 
The ratio of the initial and healed crack area was used to evaluate the healing efficacy of the bacteria. The healing ratio could not surpass $50 \%$ in the specimens with no spores, while those with the spores' encapsulation achieved a proportion in the range of 48 to $80 \%$. When water functioned as a medium during the wet and dry cycle of the samples, the highest decrease in crack area occurred. It was argued that the manual intervention may be the main drawback under typical circumstances when performing the wet cycle, as the procedure takes around $16 \mathrm{~h}$. A crack of maximum width of $1000 \mu \mathrm{m}$ was repaired using this procedure. While a capsule dosage of $5 \%$ led to less deviation, the most effective dosage for the crack healing and restoration of water permeability, was 3\%. A dosage of $5 \%$ was not considered superior, as a greater decrease in the concrete strength was observed for said dosage compared to the former.

Little to no manual intervention and inner moistures were required for the bacterial growth and activities when delivered in the inventive hydrogels encapsulation technique [10]. Furthermore, the bacteria were safeguarded in the protective shell of the capsule. When the hydrogels contained both bio-reagents and encapsulated bacteria, healing efficacy in the range of $40 \%$ to $90 \%$ was attained. Additionally, the highest reduction of $68 \%$ water permeability occurred. The retention ability of hydrogels and water uptake enabled the hydrogels-encapsulated bacteria to perform the healing effectively. At $20^{\circ} \mathrm{C}$, in an air composition with $60 \%$ relative humidity $(\mathrm{RH})$, pure hydrogels, after a day, and half a day, retained $30 \%$ and $70 \%$ of water, respectively [10]. This study indicated that the bacterial activity can be encouraged in the tropical climates by the effective retention and absorption of water that hydrogels offer, given that such climates experience high levels of precipitation and humidity. However, the non-ionic or ionic nature of the hydrogels played a significant role [10]. While retention and uptake ability of water was not impacted by the ions in the moisture for non-ionic hydrogels, for ionic hydrogels, the uptake ability was influenced by the chemicals in the air due to their sensitivity on $\mathrm{pH}$. The curing condition of dry and wet cycles lasting for $8 \mathrm{~h}$ and $16 \mathrm{~h}$, respectively was found to be the most effective regarding the healing performance upon the use of melamine-based microcapsules [25]. A substantial decrease in the contact time with water occurred when the hydrogels were used. In short, the concrete containing hydrogels possess many benefits in terms of replacing the need to manually added water, given that moisture from the air can be absorbed by the hydrogels.

The performance of the tailored sodium alginate-based hydrogels as a bacteria spore carrier was assessed [144]. The consumption of oxygen at a damaged site in the concrete was used to evaluate the suitable bacteria spores following hydrogels encapsulation. While the majority of spores maintained their encapsulated form, the concrete mixing stage led to a leakage of around $1 \%$ of the spores of the altered hydrogels. Due to the incorporation of $0.5 \%$ and $1 \%$ of the hydrogels, the values of CS and TS were reduced by $30 \%$ and $23.4 \%$, respectively, without appreciably affecting the workability of the concrete. The addition of hydrogels might have led to the formation of macro-voids and, thus, negatively influenced the strength properties of the concrete. The observed lowering in the strength and creation of voids in the concrete was the outcome of SAP addition. Contrastingly, it also enabled the development of the strength and provided the moisture for internal healing. In addition, various factors, including the age of the concrete, dosage of SAP, and water to cement ratio $(\mathrm{w} / \mathrm{c})$ determined the final outcome [145]. A decrease in the strength and lower strength development upon the incorporation of SAP were most likely due to the gel-space ratio changes when the $w$ to $c$ ratio in the concrete was above 0.45 . It was acknowledged that the specimens added with SAP could experience a diminished strength when the $\mathrm{w} / \mathrm{c}$ ratio became high, around 0.5 [144].

In the past, the precursor compound for the mineral precipitate and calcium lactate together with the porous expanded clay aggregates was used in the concrete to immobilize the bacteria spores [145]. Exposure to air stimulated the bacterial action, thereby inducing the calcium carbonate precipitation because of the fracturing of the soft and lightweight clay aggregates within the concrete network. A crack of maximum width $0.46 \mathrm{~mm}$ was 
filled when the specimen was immersed inside tap water for 14 days. Additionally, no signs of decreased viability of the bacteria were observed, even after 6 months. Bacterial precipitation activity was encouraged by the internal source of moisture provided by the clay aggregates that were widely used earlier in the lightweight concretes. Nonetheless, the pore structures, expanded clay aggregate spacing, and water in aggregate were the major factors that affected the autonomous crack healing efficacy of the clay aggregates [22]. The decrease in the strength was the main drawback to using clay aggregates rather than the standard granite aggregates. The CS of concrete depended on the toughness of the aggregates, given that the vast majority of the concrete was composed of the aggregates that are used in standard concrete. These aggregates were stronger than the concrete matrix wherein cracks eventually appeared because such strong aggregates can resist the crack formations in the standard concrete. Furthermore, the aggregates might be less tough than the matrix, especially for the clay aggregates, making it highly probable that the aggregates could break via the crack formation. Thus, the cracks were attracted to the weaker plane that generated the soft aggregates. The lightweight clay aggregates incorporated concrete after 28 days of curing revealed a decrease in the strength up to $50 \%$, making it unsuitable for structural uses [139].

Currently, the high cost of the bio-agents is the main limitation for a broad array of applications in autonomous healing. However, increasing the lifespan and resistance of autonomous healing agents for effective performance in harsh environments such that they could endure multiple cycles of loading that frequently affect the concrete structure is one way to make such agents commercially feasible. Another strategy is to reduce the production costs of bio-agents. During the lifespan of a concrete structure, the persistent deterioration necessitates multiple maintenance operations, demanding high expenditure. To explain this aspect, a life-cycle cost model was formulated by van Breugel [146], wherein it was shown that the cost incurred to build a structure may even be surpassed by the cost to repair it. In contrast, while the initial construction cost may increase due to the use of autonomously healing concrete, the total cost of the structure throughout its lifespan decreases considerably, as damages are autonomously managed without any extra cost.

One of the critical components of the autonomous healing is related to the capsules design. Identifying and producing the appropriate capsules that can impact the concrete properties is an active area of research. In fact, a very limited number of studies exist on the bio-based autonomous healing for the fatigue performance of a concrete structure. The capsules' releasing behavior determines the fatigue performance of the bio-based autonomously healing concretes. The smart or controlled release from the capsules can enable the autonomous healing of cracks when subjected to multiple loading cycles. In addition, a reduced alkalinity in the concrete matrix can lead to the corrosion of the reinforcement bars. A study was conducted to heal such deterioration via the smart release of the microcapsules [147]. Nonetheless, implementation of the smart release of capsules for the bio-based autonomous healing is a method that is essential for further replication and study to validate its potency. The incorporation of capsules provokes the formation of the weak spots in the mortar, wherein such spots can be diminished in size by the nanocapsules. Presently, in some studies, only the encapsulation of a chemical healing agent has been carried out, wherein the sonification method enabled the creation of urea formaldehyde capsules of dimension $77 \mathrm{~nm}$ (thick) and $220 \mathrm{~nm}$ (diameter) [148]. Briefly, various biological healing agents can be effectively integrated using this approach by altering the capsule material to suit the bio-agents. Furthermore, the formations of cracks in the matrix can lead to the nanoparticle agglomeration spots, wherein the nanoparticle debris must be assessed to guarantee the absence of agglomeration.

Under appropriate curing conditions of the concrete, prolonged periods in the range of 14 and 21 days were needed for the biological agents to activate the self-healing of the generated racks. Bacteria in the alkaline concrete environment produced a lower precipitation rate, justifying the need of longer durations. Higher precipitation rates and increased bacteria lifespan was achieved via the creation of genetically modified 
bacteria cultures. In was concluded that prolonged periods for curing are necessary for the activation of the biological agents in the concrete, thus, achieving quicker healing of wider cracks. Through the biological action, faster and more effective autonomous healing can be attained by placing an emphasis on the vital aspects of controlling the width of the cracks [128]. Following autonomous healing, highly effective restoration of the original properties can be obtained via the incorporation of the hybrid fibers to regulate the widths of the cracks $[149,150]$. Via the amalgamation of polymer fibers and steel, diverse healing agents and products can be placed close to the faces of the cracks in the concrete for hindering the widths of the cracks from further expansion [149].

Further investigations in a real-life construction site are required to assess the autonomous healing performance more accurately. Careful analyses of the social and environmental benefits, costs lowering strategies, and lifespan improvement of the concrete structures should be performed in the future studies. The impact of climate change acclimatization of the bio-based autonomously healing concrete was investigated [151]. The life cycle of the bio-based autonomous healing systems was enhanced by the implementation of the life cycle tests and other methods for sustainability evaluations [152]. It was acknowledged that the autonomous healing composites with more sustainable traits can be generated by mixing the carbon sequestering materials with biological healing agents [153]. It was asserted that the bio-based autonomous healing performance in actual buildings can be evaluated more accurately via the establishment of assessment standards and other stipulations. The application of the bio-based autonomous healing concrete and other such materials is a distinct possibility in the near future, as much academic attention has been placed in the field over the last decade. In essence, widespread industrial use can only occur once the present technological challenges are overcome.

\section{Sustainability of Self-Healing Concrete}

Certainly, concrete is the foremost material used in the construction industry worldwide. The formation of cracks in the concrete structure due to the entry of harmful substances through such cracks and subsequent decrease in the durability performance of the concrete must be inhibited to enhance the service life span. Deterioration of the concrete structures is more likely to happen with the ingress of corrosive substances through such cracks $[154,155]$. The incorporation of the autonomous healing materials into the concrete mix can counteract such issues. The widths of the cracks can be diminished and the concrete durability can be improved via the addition of smart autonomous healing materials into the concrete. The restoration of the strength of the cracked structures is a characteristic of the cementitious materials that form a part of the autonomous healing concrete [97]. Diverse approaches, such as microencapsulation, regular encapsulation, vascular, and direct methods have been developed to incorporate various healing agents into the concrete [98]. In addition, different artificial techniques have been adopted to enhance the efficacy of the autonomous healing in concrete. Improved outcomes were observed when water immersion conditions were combined with the incorporation of crystalline admixtures into the concrete. The FS value of the concrete was enhanced due to the incorporation of fibers and polymers with the greater proportions.

Generally, OPC-based concrete releases high amount of $\mathrm{CO}_{2}$ during the lime decarbonation and calcination reaction of the cement clinker. The $\mathrm{CO}_{2}$ emission can appreciably be lowered through the use of nanomaterial-based self-repairing technologies. Presently, advancement of the world without concrete cannot be imagined [156]. Historically, magnificent structures such as the Sydney Opera House, Chrysler Building, Taj Mahal, etc., to cite a few, were not possible to erect without concrete. In addition, the skyscrapers in the metropolis worldwide could not reach such an outstanding height without the existence of concrete. Overall, the concrete's durability and strength performance played a significant role in the erecting of numerous signposts and historical structures over the centuries in the absence of modern engineering knowledge and technologies. Undoubtedly, concrete is now an integrated component of the modern civilization. To meet the ever-increasing 
demand of sustainable and environmentally friendly construction materials, the production of functional, smart, and novel concrete became a new norm in the civil engineering sector, requiring huge investments. In fact, every year, an enormous amount of raw materials are discarded as wastes because of ineffective concrete manufacturing processes. Furthermore, the worldwide manufacturing of the main concrete binder called OPC is responsible for the emission of more than $5 \%$ of the entire greenhouse gases yearly. It has become a serious concern regarding environmental pollution and global warming. Modern civilization must aim to perform future construction using green, sustainable materials together with environmentally friendly technologies [157]. Thus, it is important to build more unconventional, efficient, clean, sustainable, safe, reliable, and strong functional construction materials as substitute to the OPC-based concrete. To mitigate the environmental problems, nanomaterials-based smart concretes and self-healing technologies became an emergent area with several implications.

An increased service life span of the concrete structures can lower the demand of new structural materials. Thus, the uses of the resource raw materials be can radically lowered and the pollution level of $\mathrm{CO}_{2}$ emission can be diminished together with the low consumption of energy. Repeated research has revealed that a substantial cost is involved in maintaining and repairing poor construction quality as well as low durability performance of the concrete in the construction sectors. In the US, the cost for reconstructing bridges is estimated to be in the range of USD 20 to 200 billion [158], wherein the average maintenance costs for these bridges per year is about USD 5.2 billion. Detailed analyses of the life cycle clearly indicated that the indirect expenditure due to traffic jam and related low output is 10 times higher than the direct one spent for their maintenance and repairs [159]. The Netherlands spent about one-third of their annual budget on the inspection, monitoring, maintenance, up-gradation, and repair of the outsized civil engineering construction works. The repairing and maintenance cost of the construction in the United Kingdom is more than $45 \%$ of their annual spending $[160,161]$. The department for environment, food, and rural affairs (DEFRA) reports showed that nearly half of $\mathrm{CO}_{2}$ emissions in the UK were due to poor-quality building structures. For instance, the manufacturing of 1 tons of OPC is responsible for the emission of 1 tons of $\mathrm{CO}_{2}$ because of the calcination and fuel combustion process [162,163].

Worldwide, approximately $2.35 \times 10^{9}$ tons of cement is manufactured per year, which results in major emissions of $\mathrm{CO}_{2}$, nearly $5-7 \%$ of the total $\mathrm{CO}_{2}$ emissions in the world. The rapid expansion of the economy of China and India caused the largest consumption of cement, which is anticipated to amplify if the present technologies that are used to manufacture cement remains unaltered. Enhancement of the durability and reduction of the repair costs of the building infrastructures can certainly lessen the negative impact of cement and related pollution due to greenhouse gases emission, thus, improving our activities and stabilizing the biosphere. In this view, it is necessary to perform more studies and look for promising solutions for the future sustainable development. In-depth understanding of the negative impact of the construction materials on our environment is expected to benefit several stakeholders concerned with the construction industries, improving the quality of social life and service life span of the concrete structures, thereby meeting the sustainable goals. Traditionally, concrete structures have been designed to fulfill the desired specifications in the beginning of its service life. Then, the durability of such structures has been monitored via the maintenance plans. Lately, material scientists have adopted some new strategies by considering the adaptability or self-healing properties of the materials over the service life span of the construction materials. This inspiration of using new functional and smart materials in the construction industries has appeared from nature via the bio-mimicry of diverse living organisms. Motivated by the feasibility of achieving selfhealing concrete structures, some of the pioneering research has focused on both natural capacity of hydrates to heal cracks over a certain period, as well as artificial ways to repair cracks using adhesive reservoirs embedment into the concrete network matrix. 


\section{Conclusions}

This review article analyzed and compared various relevant studies on sundry smart bio-agents-activated sustainable self-healing cementitious materials. In addition, many state-of-the-art tests and methods used to assess the self-healing efficiency of such smart bio-materials beneficial for the green construction were underscored. An all-inclusive overview of the appropriate literature on smart bio-materials-based self-healing concrete was performed in this study, which allowed us to draw the following conclusions:

i. The design of bio-materials-based self-healing concretes with improved performance and endurance useful for several applications is a new avenue in the smart concreteenabled construction industry.

ii. Systematic integration of self-healing smart materials for both construction information and physical indices, such as mechanical strength and durability, are essential to enhance their functionality via the autonomous self-healing. The self-healing efficacy of such functional materials is characterized by their capacity to lower the cracks' widths, lengths, and depths when inspected visually.

iii. Generally, the recovery tests for the strength characteristics are conducted to assess the self-healing efficacy of the cited materials. Various tests at the scale of macroand micro-structures have been performed to achieve the most reliable outcomes regarding the self-healing efficiency of the materials. However, tests at the nanoscale remain deficient.

iv. Inclusion of bacteria as a self-healing agent in the cementitious matrices was shown to enhance the compressive strength recovery of concrete. Furthermore, the combination of fibers and bacteria in the self-healing materials was observed to improve their flexural and splitting tensile strengths.

v. Regarding the durability, uses of bacteria in the concrete structures was found to decrease the water permeability and chloride ions penetrability. Some studies disclosed that the use of bacteria in the concrete structures provide improved performance of cracks' healing and excellent mechanical strengths.

vi. It was asserted that microbial concrete, owing to its cost-effectiveness and environmental friendliness, may be a viable substitute to the traditional cement-based concrete. Such concrete can potentially be used as high-performance concrete sealant, leading to durability enhancement of the sustainable construction materials. Presently, the cost of bio-agents incorporation into concrete is relatively high. To lower the overall cost, strategies such as the reduction in the bio-agents production cost and self-healing activity design with durability for the commercial viability of the self-repairing products were adopted. Such materials are expected to perform well under multiple loading cycles and harsh environmental conditions.

vii. Capsules design and insertion in concrete are the vital components to achieve improved self-healing traits. Recent findings indicated that the time taken for the closure of cracks in the bio-agents-activated self-healing process under suitable curing conditions is too long, characteristically spanning over two to three weeks.

viii. Self-healing smart concretes are characterized by many significant traits, such as producing less pollution, eco-efficiency, and elevated durability performance in harsh environments. These properties make them effective sustainable materials in the construction industries.

ix. With continued development and seamless integration of self-healing materials into modern-day applications, it is set to open a new era of enhanced consumer experience, infrastructures maintenance and environmental management, as well as countless unprecedented and unique applications.

x. Research is a continuous process in human development; it is generally believed that today's research is tomorrow's wealth. Therefore, the effect of different types of concretes and their $\mathrm{pH}$ values on the performance of the smart biomaterials-based self-healing are highly recommended for future studies. 


\begin{abstract}
Author Contributions: G.F.H.: Conceptualization, Methodology, Writing-Original draft preparation; M.L.N.: Conceptualization, Supervision, Writing—review and editing; I.F.: Verify the manuscript structure and supervised the overall research, Project administration, Supervision; S.K.G.: Visualization, Validation, Writing-review and editing; H.K.H.: Visualization, Validation; O.B.: Visualization, Validation; F.A.: Visualization, Validation, Supervision, Writing-review and editing. All authors have read and agreed to the published version of the manuscript.
\end{abstract}

Funding: The authors are grateful to UTM Malaysia (UTMFR 20H65) and RMC for the financial and technical assistance.

Institutional Review Board Statement: Not applicable.

Informed Consent Statement: Not applicable.

Data Availability Statement: Data is contained within the article.

Conflicts of Interest: The authors declare no conflict of interest.

$\begin{array}{ll}\text { Abbreviations } \\ \text { CS } & \text { Compressive strength } \\ \text { ECC } & \text { Engineered cementitious composite } \\ \text { SCMs } & \text { Supplementary cementitious materials } \\ \text { UPV } & \text { Ultrasonic pulse velocity } \\ \text { FS } & \text { Flexural strength } \\ \text { TS } & \text { Tensile strength } \\ \text { XRD } & \text { X-ray diffraction } \\ \text { FESEM } & \text { Field emission scanning electron microscopy } \\ \text { SEM } & \text { Scanning electron microscopy } \\ \text { EDS } & \text { Energy-dispersive X-ray } \\ \text { CA } & \text { Crystalline additives } \\ \text { CSA } & \text { Expansive additives } \\ \text { SAP } & \text { Superabsorbent polymer } \\ \text { FRCC } & \text { Fiber reinforced cementitious concrete } \\ \text { PVA } & \text { Polyvinyl alcohol } \\ \text { FA } & \text { Fly ash } \\ \text { GNP } & \text { Graphite nanoplatelets } \\ \text { LWA } & \text { Light weight aggregates } \\ \text { CERUP } & \text { Cyclic EnRiched ureolytic powder } \\ \text { OPC } & \text { Ordinary Portland cement }\end{array}$

\title{
References
}

1. Alyousef, R.; Ebid, A.A.K.; Huseien, G.F.; Mohammadhosseini, H.; Alabduljabbar, H.; Poi Ngian, S.; Mohamed, A.M. Effects of Sulfate and Sulfuric Acid on Efficiency of Geopolymers as Concrete Repair Materials. Gels 2022, 8, 53. [CrossRef] [PubMed]

2. Asaad, M.A.; Huseien, G.F.; Memon, R.P.; Ghoshal, S.K.; Mohammadhosseini, H.; Alyousef, R. Enduring Performance of Alkali-activated Mortars with Metakaolin as Granulated Blast Furnace Slag Replacement. Cas. Stud. Const. Mater. 2021, e00845. [CrossRef]

3. Aldea, C.-M.; Shah, S.; Karr, A. Permeability of cracked concrete. Mater. Struct. 1999, 32, 370-376. [CrossRef]

4. Huseien, G.F.; Mirza, J.; Ismail, M.; Ghoshal, S.; Hussein, A.A. Geopolymer mortars as sustainable repair material: A comprehensive review. Renew. Sustain. Energy Rev. 2017, 80, 54-74. [CrossRef]

5. Nodehi, M.; Ozbakkaloglu, T.; Gholampour, A. A systematic review of bacteria-based self-healing concrete: Biomineralization, mechanical, and durability properties. J. Build. Eng. 2022, 104038. [CrossRef]

6. Huseien, G.F.; Mirza, J.; Ariffin, N.F.; Hussin, M.W. Synthesis and Characterization of Self-Healing Mortar with Modified Strength. J. Teknol. 2015, 76, 195-200. [CrossRef]

7. Shah, K.W.; Huseien, G.F. Bond strength performance of ceramic, fly ash and GBFS ternary wastes combined alkali-activated mortars exposed to aggressive environments. Constr. Build. Mater. 2020, 251, 119088. [CrossRef]

8. Huseien, G.F.; Shah, K.W. Performance evaluation of alkali-activated mortars containing industrial wastes as surface repair materials. J. Build. Eng. 2020, 30, 101234. [CrossRef]

9. Hager, M.D.; Greil, P.; Leyens, C.; van der Zwaag, S.; Schubert, U.S. Self-healing materials. Adv. Mater. 2010, 22, 5424-5430. [CrossRef] [PubMed] 
10. Bekas, D.; Tsirka, K.; Baltzis, D.; Paipetis, A. Self-healing materials: A review of advances in materials, evaluation, characterization and monitoring techniques. Compos. Part B Eng. 2016, 87, 92-119. [CrossRef]

11. Guo, Y.C.; Wang, X.; Yan, Z.; Zhong, H. Current progress on biological self-healing concrete. Mater. Res. Innov. 2015, 19, S8-S750. [CrossRef]

12. Shah, K.W.; Huseien, G.F. Biomimetic self-healing cementitious construction materials for smart Buildings. Biomimetics 2020,5 , 47. [CrossRef] [PubMed]

13. Van Tittelboom, K.; De Belie, N.; De Muynck, W.; Verstraete, W. Use of bacteria to repair cracks in concrete. Cem. Concr. Res. 2010, 40, 157-166. [CrossRef]

14. Luo, J.; Chen, X.; Crump, J.; Zhou, H.; Davies, D.G.; Zhou, G.; Zhang, N.; Jin, C. Interactions of fungi with concrete: Significant importance for bio-based self-healing concrete. Constr. Build. Mater. 2018, 164, 275-285. [CrossRef]

15. Algaifi, H.A.; Abu Bakar, S.; Sam, A.R.M.; Abidin, A.R.Z.; Shahir, S.; Al-Towayti, W.A.H. Numerical modeling for crack self-healing concrete by microbial calcium carbonate. Constr. Build. Mater. 2018, 189, 816-824. [CrossRef]

16. De Belie, N.; Gruyaert, E.; Al-Tabbaa, A.; Antonaci, P.; Baera, C.; Bajare, D.; Darquennes, A.; Davies, R.; Ferrara, L.; Jefferson, T.; et al. A Review of Self-Healing Concrete for Damage Management of Structures. Adv. Mater. Interfaces 2018, 5, 1800074. [CrossRef]

17. Gollapudi, U.; Knutson, C.; Bang, S.; Islam, M. A new method for controlling leaching through permeable channels. Chemosphere 1995, 30, 695-705. [CrossRef]

18. Huseien, G.F.; Shah, K.W.; Sam, A.R.M. Sustainability of nanomaterials based self-healing concrete: An all-inclusive insight. J. Build. Eng. 2019, 23, 155-171. [CrossRef]

19. Vijay, K.; Murmu, M.; Deo, S.V. Bacteria based self healing concrete-A review. Constr. Build. Mater. 2017, 152, 1008-1014. [CrossRef]

20. Mostavi, E.; Asadi, S.; Hassan, M.M.; Alansari, M. Evaluation of Self-Healing Mechanisms in Concrete with Double-Walled Sodium Silicate Microcapsules. J. Mater. Civ. Eng. 2015, 27, 04015035. [CrossRef]

21. Khaliq, W.; Ehsan, M.B. Crack healing in concrete using various bio influenced self-healing techniques. Constr. Build. Mater. 2016, 102, 349-357. [CrossRef]

22. Gupta, S.; Dai Pang, S.; Kua, H.W. Autonomous healing in concrete by bio-based healing agents-A review. Constr. Build. Mater. 2017, 146, 419-428. [CrossRef]

23. Worrell, E.; Price, L.; Martin, N.; Hendriks, C.; Meida, L.O. Carbon dioxide emissions from the global cement industry. Annu. Rev. Energy Environ. 2001, 26, 303-329. [CrossRef]

24. De Muynck, W.; De Belie, N.; Verstraete, W. Microbial carbonate precipitation in construction materials: A review. Ecol. Eng. 2010, 36, 118-136. [CrossRef]

25. Wang, J.; Soens, H.; Verstraete, W.; De Belie, N. Self-healing concrete by use of microencapsulated bacterial spores. Cem. Concr. Res. 2014, 56, 139-152. [CrossRef]

26. Wang, J.; Van Tittelboom, K.; De Belie, N.; Verstraete, W. Use of silica gel or polyurethane immobilized bacteria for self-healing concrete. Constr. Build. Mater. 2012, 26, 532-540. [CrossRef]

27. Pei, R.; Liu, J.; Wang, S.; Yang, M. Use of bacterial cell walls to improve the mechanical performance of concrete. Cem. Concr. Compos. 2013, 39, 122-130. [CrossRef]

28. Luna-Finkler, C.L.; Finkler, L. Bacillus Sphaericus and Bacillus Thuringiensis to Insect Control: Process Development of Small Scale Production to Pilot-Plant-Fermenters; INTECH Open Access Publisher: London, UK, 2012; pp. 613-628.

29. Wang, J.Y.; De Belie, N.; Verstraete, W. Diatomaceous earth as a protective vehicle for bacteria applied for self-healing concrete. J. Ind. Microbiol. Biotechnol. 2012, 39, 567-577. [CrossRef]

30. Wang, J.; Snoeck, D.; Van Vlierberghe, S.; Verstraete, W.; De Belie, N. Application of hydrogel encapsulated carbonate precipitating bacteria for approaching a realistic self-healing in concrete. Constr. Build. Mater. 2014, 68, 110-119. [CrossRef]

31. Wu, M.; Johannesson, B.; Geiker, M. A review: Self-healing in cementitious materials and engineered cementitious composite as a self-healing material. Constr. Build. Mater. 2012, 28, 571-583. [CrossRef]

32. Sangadji, S.; Schlangen, E. Mimicking Bone Healing Process to Self Repair Concrete Structure Novel Approach Using Porous Network Concrete. Procedia Eng. 2013, 54, 315-326. [CrossRef]

33. Talaiekhozani, A.; Abd Majid, M.Z. A review of self-healing concrete research development. J. Environ. Treat. Tech. 2014, 2, 1-11.

34. Vickers, N.J. Animal communication: When i'm calling you, will you answer too? Curr. Biol. 2017, 27, R713-R715. [CrossRef]

35. Huseien, G.F.; Joudah, Z.H.; Memon, R.P.; Sam, A.R.M. Compressive strength and microstructure properties of modified concrete incorporated effective microorganism and fly ash. Mater. Today Proc. 2021, 46, 2036-2044.

36. Schlangen, E.; Sangadji, S. Addressing Infrastructure Durability and Sustainability by Self Healing Mechanisms-Recent Advances in Self Healing Concrete and Asphalt. Procedia Eng. 2013, 54, 39-57. [CrossRef]

37. Parks, J.; Edwards, M.; Vikesland, P.; Dudi, A. Effects of Bulk Water Chemistry on Autogenous Healing of Concrete. J. Mater. Civ. Eng. 2010, 22, 515-524. [CrossRef]

38. Yang, Y.; Yang, E.-H.; Li, V. Autogenous healing of engineered cementitious composites at early age. Cem. Concr. Res. 2011, 41, 176-183. [CrossRef]

39. Nishiwaki, T.; Kwon, S.; Homma, D.; Yamada, M.; Mihashi, H. Self-Healing Capability of Fiber-Reinforced Cementitious Composites for Recovery of Watertightness and Mechanical Properties. Materials 2014, 7, 2141-2154. [CrossRef] 
40. Huang, H.; Ye, G.; Damidot, D. Effect of blast furnace slag on self-healing of microcracks in cementitious materials. Cem. Concr. Res. 2014, 60, 68-82. [CrossRef]

41. Ahn, T.; Kim, D.; Kang, S. Crack Self-Healing Behavior of High Performance Fiber Reinforced Cement Composites under Various Environmental Conditions. In Earth and Space 2012: Engineering, Science, Construction, and Operations in Challenging Environments; ASCE: Reston, VA, USA, 2012; pp. 635-640.

42. Kishi, T.; Kobayashi, K.; Komatsu, S.; Hosoda, A.; Ikeno, S.; Ahn, T. Self Healing Properties with Various Crack Widths under Continuous Water Leakage. In Concrete Repair, Rehabilitation and Retrofitting II; CRC Press: Boca Raton, FL, USA, 2008; pp. 139-140.

43. Lv, Z.; Chen, D. Overview of Recent Work on Self-Healing in Cementitious Materials. Mater. Construcción 2014, 64, e034. [CrossRef]

44. Yıldırım, G.; Keskin, Ö.K.; Keskin, S.B.; Şahmaran, M.; Lachemi, M. A review of intrinsic self-healing capability of engineered cementitious composites: Recovery of transport and mechanical properties. Constr. Build. Mater. 2015, 101, 10-21. [CrossRef]

45. Siad, H.; Alyousif, A.; Keskin, O.K.; Keskin, S.B.; Lachemi, M.; Sahmaran, M.; Hossain, K.M.A. Influence of limestone powder on mechanical, physical and self-healing behavior of Engineered Cementitious Composites. Constr. Build. Mater. 2015, 99, 1-10. [CrossRef]

46. In, C.-W.; Holland, R.B.; Kim, J.-Y.; Kurtis, K.E.; Kahn, L.F.; Jacobs, L.J. Monitoring and evaluation of self-healing in concrete using diffuse ultrasound. NDT E Int. 2013, 57, 36-44. [CrossRef]

47. Wang, J.; Dewanckele, J.; Cnudde, V.; Van Vlierberghe, S.; Verstraete, W.; De Belie, N. X-ray computed tomography proof of bacterial-based self-healing in concrete. Cem. Concr. Compos. 2014, 53, 289-304. [CrossRef]

48. Snoeck, D.; Van Tittelboom, K.; Steuperaert, S.; Dubruel, P.; De Belie, N. Self-healing cementitious materials by the combination of microfibres and superabsorbent polymers. J. Intell. Mater. Syst. Struct. 2014, 25, 13-24. [CrossRef]

49. Abd_Elmoaty, A.E.M. Self-healing of polymer modified concrete. Alex. Eng. J. 2011, 50, 171-178. [CrossRef]

50. Van Tittelboom, K.; De Belie, N. Self-Healing in Cementitious Materials-A Review. Materials 2013, 6, 2182-2217. [CrossRef]

51. Hazelwood, T.; Jefferson, A.; Lark, R.; Gardner, D. Numerical simulation of the long-term behaviour of a self-healing concrete beam vs standard reinforced concrete. Eng. Struct. 2015, 102, 176-188. [CrossRef]

52. Ariffin, N.F.; Hussin, M.W.; Sam, A.R.M.; Lee, H.S.; Khalid, N.H.A.; Lim, N.H.A.S.; Samadi, M. Mechanical properties and self-healing mechanism of epoxy mortar. J. Teknol. 2015, 77, 37-44. [CrossRef]

53. Sam, A.R.M.; Ariffin, N.F.; Hussin, M.W.; Lee, H.S.; Ismail, M.; Lim, N.H.A.S.; Khalid, N.H.A.; Samadi, M.; Mirza, J.; Majid, M.Z.A. Performance of epoxy resin as self-healing agent. J. Teknol. 2015, 77, 9-13. [CrossRef]

54. Van Tittelboom, K.; Wang, J.; Araújo, M.; Snoeck, D.; Gruyaert, E.; Debbaut, B.; Derluyn, H.; Cnudde, V.; Tsangouri, E.; Van Hemelrijck, D.; et al. Comparison of different approaches for self-healing concrete in a large-scale lab test. Constr. Build. Mater. 2016, 107, 125-137. [CrossRef]

55. Sanchez, F.; Sobolev, K. Nanotechnology in concrete-A review. Constr. Build. Mater. 2010, 24, 2060-2071. [CrossRef]

56. Sobolev, K.; Flores, I.; Hermosillo, R.; Torres-Martínez, L.M. Application of nanomaterials in high-performance cement composites. In Proceedings of the ACI Session on Nanotechnology of Concrete: Recent Developments and Future Perspectives, Denver, CO, USA, 7 November 2006; pp. 93-120.

57. Perez, G.; Erkizia, E.; Gaitero, J.; Kaltzakorta, I.; Jiménez, I.; Guerrero, A. Synthesis and characterization of epoxy encapsulating silica microcapsules and amine functionalized silica nanoparticles for development of an innovative self-healing concrete. Mater. Chem. Phys. 2015, 165, 39-48. [CrossRef]

58. Morsy, M.S.; Alsayed, S.H.; Aqel, M. Hybrid effect of carbon nanotube and nano-clay on physico-mechanical properties of cement mortar. Constr. Build. Mater. 2011, 25, 145-149. [CrossRef]

59. Muhammad, N.Z.; Keyvanfar, A.; Majid, M.Z.A.; Shafaghat, A.; Mirza, J. Waterproof performance of concrete: A critical review on implemented approaches. Constr. Build. Mater. 2015, 101, 80-90. [CrossRef]

60. Jonkers, H.M.; Schlangen, E. Development of a bacteria-based self healing concrete. In Tailor Made Concrete Structures; Walraven, J.C., Stoelhorst, D., Eds.; Taylor \& Francis Group: London, UK, 2008; pp. 425-430, ISBN 978-0-415-47535-8.

61. Talaiekhozani, A.; Keyvanfar, A.; Andalib, R.; Samadi, M.; Shafaghat, M.; Kamyab, H.; Abd Majid, M.; Mohamad Zin, R.; Fulazzaky, M.A.; Lee, C.T. Application of Proteus mirabilis and Proteus vulgaris mixture to design self-healing concrete. Desalination Water Treat. 2014, 52, 3623-3630. [CrossRef]

62. Jonkers, H.M.; Schlangen, E. A Two Component Bacteria-Based Self-Healing Concrete. In Concrete Repair, Rehabilitation and Retrofitting II; CRC Press: Boca Raton, FL, USA, 2008; pp. 137-138.

63. Wiktor, V.; Jonkers, H. Field performance of bacteria-based repair system: Pilot study in a parking garage. Case Stud. Constr. Mater. 2015, 2, 11-17. [CrossRef]

64. Ghosh, P.; Mandal, S.; Chattopadhyay, B.; Pal, S. Use of microorganism to improve the strength of cement mortar. Cem. Concr. Res. 2005, 35, 1980-1983. [CrossRef]

65. Achal, V.; Pan, X.; Özyurt, N. Improved Strength and Durability of Fly Ash-Amended Concrete by Microbial Calcite Precipitation. Ecol. Eng. 2011, 37, 554-559. [CrossRef]

66. Achal, V.; Mukherjee, A.; Reddy, M.S. Microbial Concrete: Way to Enhance the Durability of Building Structures. J. Mater. Civ. Eng. 2011, 23, 730-734. [CrossRef]

67. Bang, S.S.; Galinat, J.K.; Ramakrishnan, V. Calcite precipitation induced by polyurethane-immobilized Bacillus pasteurii. Enzym. Microb. Technol. 2001, 28, 404-409. [CrossRef] 
68. Irwan, J.; Othman, N. An Overview of Bioconcrete for Structural Repair. In Applied Mechanics and Materials; Trans Tech Publications: Zurich, Switzerland, 2013; Volume 389, pp. 36-39.

69. Qian, C.X.; Luo, M.; Ren, L.F.; Wang, R.X.; Li, R.Y.; Pan, Q.F.; Chen, H.C. Self-Healing and Repairing Concrete Cracks Based on Bio-Mineralization. In Key Engineering Materials; Trans Tech Publications: Zurich, Switzerland, 2015; Volume 630, pp. 494-503.

70. de Koster, S.; Mors, R.; Nugteren, H.; Jonkers, H.; Meesters, G.; van Ommen, J.R. Geopolymer Coating of Bacteria-containing Granules for Use in Self-healing Concrete. Procedia Eng. 2015, 102, 475-484. [CrossRef]

71. Mors, R.M.; Jonkers, H.M. Bacteria-Based Self-Healing Concrete: An Introduction. In V International PhD Student Workshop on Durability of Reinforced Concrete: From Composition to Service Life Design. VTT Technology 65; VTT Technical Research Center: Espoo, Finland, 2012; pp. 32-39.

72. Otsuki, N.; Miyazato, S.; Diola, N.; Suzuki, H. Influences of bending crack and water-cement ratio on chloride-induced corrosion of main reinforcing bars and stirrups. Mater. J. 2000, 97, 454-464.

73. Kessler, M. Self-healing: A new paradigm in materials design. Inst. Mech. Eng. Part G J. Aerosp. Eng. 2007, 221, 479-495. [CrossRef]

74. Trask, R.S.; Williams, H.R.; Bond, I.P. Self-healing polymer composites: Mimicking nature to enhance performance. Bioinspir. Biomim. 2007, 2, P1-P9. [CrossRef] [PubMed]

75. White, S.R.; Sottos, N.R.; Geubelle, P.H.; Moore, J.S.; Kessler, M.R.; Sriram, S.R.; Brown, E.N.; Viswanathan, S. Autonomic healing of polymer composites. Nature 2001, 409, 794-797. [CrossRef] [PubMed]

76. Li, H.; Cui, Y.; Wang, H.; Zhu, Y.; Wang, B. Preparation and application of polysulfone microcapsules containing tung oil in self-healing and self-lubricating epoxy coating. Colloids Surfaces Physicochem. Eng. Asp. 2017, 518, 181-187. [CrossRef]

77. Ghosh, S.K. Self-Healing Materials: Fundamentals, Design Strategies, and Applications; John Wiley \& Sons: Hoboken, NJ, USA, 2009; pp. 1-28.

78. Therriault, D.; White, S.; Lewis, J.A. Chaotic mixing in three-dimensional microvascular networks fabricated by direct-write assembly. Nat. Mater. 2003, 2, 265-271. [CrossRef] [PubMed]

79. Therriault, D.; Shepherd, R.F.; White, S.R.; Lewis, J.A. Fugitive Inks for Direct-Write Assembly of Three-Dimensional Microvascular Networks. Adv. Mater. 2005, 17, 395-399. [CrossRef]

80. Muhammad, N.Z.; Shafaghat, A.; Keyvanfar, A.; Majid, M.Z.A.; Ghoshal, S.; Yasouj, S.E.M.; Ganiyu, A.A.; Kouchaksaraei, M.S.; Kamyab, H.; Taheri, M.M.; et al. Tests and methods of evaluating the self-healing efficiency of concrete: A review. Constr. Build. Mater. 2016, 112, 1123-1132. [CrossRef]

81. Feiteira, J.; Gruyaert, E.; De Belie, N. Self-Healing of Dynamic Concrete Cracks Using Polymer Precursors as Encapsulated Healing Agents; Concrete Solutions; Taylor \& Francis Group: Ghent, Belgium, 2014; pp. 65-69.

82. Liu, B.; Zhang, J.L.; Ke, J.L.; Deng, X.; Dong, B.Q.; Han, N.X.; Xing, F. Trigger of self-healing process induced by EC encapsulated mineralization bacterium and healing efficiency in cement paste specimens. In Proceedings of the 5th International Conference on Self-Healing Materials, Durham, CO, USA, 22-24 June 2015.

83. Achal, V.; Mukerjee, A.; Reddy, M.S. Biogenic treatment improves the durability and remediates the cracks of concrete structures. Constr. Build. Mater. 2013, 48,1-5. [CrossRef]

84. Pang, B.; Zhou, Z.; Hou, P.; Du, P.; Zhang, L.; Xu, H. Autogenous and engineered healing mechanisms of carbonated steel slag aggregate in concrete. Constr. Build. Mater. 2016, 107, 191-202. [CrossRef]

85. Luo, M.; Qian, C.-X.; Li, R.-Y. Factors affecting crack repairing capacity of bacteria-based self-healing concrete. Constr. Build. Mater. 2015, 87, 1-7. [CrossRef]

86. Li, W.; Jiang, Z.; Yang, Z.; Zhao, N.; Yuan, W. Self-Healing Efficiency of Cementitious Materials Containing Microcapsules Filled with Healing Adhesive: Mechanical Restoration and Healing Process Monitored by Water Absorption. PLoS ONE 2013, 8 , e81616. [CrossRef] [PubMed]

87. Cao, Q.Y.; Hao, T.Y.; Su, B. Crack Self-Healing Properties of Concrete with Adhesive. Adv. Mater. Res. 2014, 919-921, 1880-1884. [CrossRef]

88. Luhar, S.; Gourav, S. A review paper on self healing concrete. J. Civ. Eng. Res. 2015, 5, 53-58.

89. Sarkar, M.; Chowdhury, T.; Chattopadhyay, B.; Gachhui, R.; Mandal, S. Autonomous bioremediation of a microbial protein (bioremediase) in Pozzolana cementitious composite. J. Mater. Sci. 2014, 49, 4461-4468. [CrossRef]

90. Dong, B.; Han, N.; Zhang, M.; Wang, X.; Cui, H.; Xing, F. A Microcapsule Technology Based Self-Healing System for Concrete Structures. J. Earthq. Tsunami 2013, 7, 1350014. [CrossRef]

91. Kanellopoulos, A.; Qureshi, T.; Al-Tabbaa, A. Glass encapsulated minerals for self-healing in cement based composites. Constr. Build. Mater. 2015, 98, 780-791. [CrossRef]

92. Granger, S.; Pijaudier-Cabot, G.; Loukili, A. Mechanical behavior of self-healed ultra high performance concrete: From experimental evidence to modeling. In Proceedings of the 6th International Conference on Fracture Mechanics of Concrete and Concrete Structures, Catalina, Italy, 17-22 June 2007.

93. Huang, H.; Ye, G. Self-healing of cracks in cement paste affected by additional $\mathrm{Ca}^{2+}$ ions in the healing agent. J. Intell. Mater. Syst. Struct. 2015, 26, 309-320. [CrossRef]

94. Xu, J.; Yao, W. Multiscale mechanical quantification of self-healing concrete incorporating non-ureolytic bacteria-based healing agent. Cem. Concr. Res. 2014, 64, 1-10. [CrossRef]

95. Huseien, G.F.; Joudah, Z.H.; Khalid, N.H.A.; Sam, A.R.M.; Tahir, M.M.; Lim, N.H.A.S.; Mirza, J. Durability performance of modified concrete incorporating fly ash and effective microorganism. Constr. Build. Mater. 2021, 267, 120947. [CrossRef] 
96. Reddy, C.M.K.; Ramesh, B.; Macrin, D. Effect of crystalline admixtures, polymers and fibers on self healing concrete-a review. Mater. Today Proc. 2020, 33, 763-770. [CrossRef]

97. Reddy, T.C.S.; Theja, R. Macro mechanical properties of self-healing concrete with crystalline admixture under different environments. Ain Shams Eng. J. 2019, 10, 23-32. [CrossRef]

98. Roig-Flores, M.; Moscato, S.; Serna, P.; Ferrara, L. Self-healing capability of concrete with crystalline admixtures in different environments. Constr. Build. Mater. 2015, 86, 1-11. [CrossRef]

99. Roig-Flores, M.; Pirritano, F.; Serna, P.; Ferrara, L. Effect of crystalline admixtures on the self-healing capability of early-age concrete studied by means of permeability and crack closing tests. Constr. Build. Mater. 2016, 114, 447-457. [CrossRef]

100. Sisomphon, K.; Copuroglu, O.; Koenders, E. Self-healing of surface cracks in mortars with expansive additive and crystalline additive. Cem. Concr. Compos. 2012, 34, 566-574. [CrossRef]

101. Krelani, V.; Ferrara, L. Self-healing capacity of concrete with crystalline additives: Natural vs. accelerated exposure conditions. In Proceedings of the International Conference on Self-Healing Materials (ICSHM2013), Ghent, Belgium, 16-20 June 2013.

102. Van Tittelboom, K.; De Belie, N.; Van Loo, D.; Jacobs, P. Self-healing efficiency of cementitious materials containing tubular capsules filled with healing agent. Cem. Concr. Compos. 2011, 33, 497-505. [CrossRef]

103. Araújo, M.; Van Tittelboom, K.; Dubruel, P.; Van Vlierberghe, S.; De Belie, N. Acrylate-endcapped polymer precursors: Effect of chemical composition on the healing efficiency of active concrete cracks. Smart Mater. Struct. 2017, 26, 055031. [CrossRef]

104. Gruyaert, E.; Debbaut, B.; Snoeck, D.; Díaz, P.; Arizo, A.; Tziviloglou, E.; Schlangen, E. Self-healing mortar with pH-sensitive superabsorbent polymers: Testing of the sealing efficiency by water flow tests. Smart Mater. Struct. 2016, 25, 084007. [CrossRef]

105. Yang, Z.; Hollar, J.; He, X.; Shi, X. Laboratory Assessment of a Self-Healing Cementitious Composite. Transp. Res. Rec. J. Transp. Res. Board 2010, 2142, 9-17. [CrossRef]

106. Feiteira, J.; Gruyaert, E.; De Belie, N. Self-healing of moving cracks in concrete by means of encapsulated polymer precursors. Constr. Build. Mater. 2016, 102,671-678. [CrossRef]

107. Lee, H.; Wong, H.; Buenfeld, N. Self-sealing of cracks in concrete using superabsorbent polymers. Cem. Concr. Res. 2016, 79, 194-208. [CrossRef]

108. Kwon, S.; Mihashi, H.; Nishiwaki, T. Experimental study on self-healing capability of cracked ultra-high-performance hybridfiber-reinforced cementitious composites. In Proceedings of the 3rd International Conference on Sustainable Construction Materials and Technologies, Kyoto, Japan, 19-21 August 2013.

109. Nishiwaki, T.; Koda, M.; Yamada, M.; Mihashi, H.; Kikuta, T. Experimental Study on Self-Healing Capability of FRCC Using Different Types of Synthetic Fibers. J. Adv. Concr. Technol. 2012, 10, 195-206. [CrossRef]

110. Kim, S.; Yoo, D.-Y.; Kim, M.-J.; Banthia, N. Self-healing capability of ultra-high-performance fiber-reinforced concrete after exposure to cryogenic temperature. Cem. Concr. Compos. 2019, 104, 103335. [CrossRef]

111. Feng, J.; Su, Y.; Qian, C. Coupled effect of PP fiber, PVA fiber and bacteria on self-healing efficiency of early-age cracks in concrete. Constr. Build. Mater. 2019, 228, 116810. [CrossRef]

112. Singh, H.; Gupta, R. Influence of cellulose fiber addition on self-healing and water permeability of concrete. Case Stud. Constr. Mater. 2019, 12, e00324. [CrossRef]

113. Luo, M.; Qian, C. Influences of bacteria-based self-healing agents on cementitious materials hydration kinetics and compressive strength. Constr. Build. Mater. 2016, 121, 659-663. [CrossRef]

114. Hung, C.-C.; Su, Y.-F. Medium-term self-healing evaluation of Engineered Cementitious Composites with varying amounts of fly ash and exposure durations. Constr. Build. Mater. 2016, 118, 194-203. [CrossRef]

115. Tziviloglou, E.; Wiktor, V.; Jonkers, H.; Schlangen, E. Bacteria-based self-healing concrete to increase liquid tightness of cracks. Constr. Build. Mater. 2016, 122, 118-125. [CrossRef]

116. De Muynck, W.; Debrouwer, D.; De Belie, N.; Verstraete, W. Bacterial carbonate precipitation improves the durability of cementitious materials. Cem. Concr. Res. 2008, 38, 1005-1014. [CrossRef]

117. Siddique, R.; Singh, K.; Kunal; Singh, M.; Corinaldesi, V.; Rajor, A. Properties of bacterial rice husk ash concrete. Constr. Build. Mater. 2016, 121, 112-119. [CrossRef]

118. Andalib, R.; Majid, M.Z.A.; Hussin, M.W.; Ponraj, M.; Keyvanfar, A.; Mirza, J.; Lee, H.-S. Optimum concentration of Bacillus megaterium for strengthening structural concrete. Constr. Build. Mater. 2016, 118, 180-193. [CrossRef]

119. Chahal, N.; Siddique, R.; Rajor, A. Influence of bacteria on the compressive strength, water absorption and rapid chloride permeability of fly ash concrete. Constr. Build. Mater. 2012, 28, 351-356. [CrossRef]

120. Anne, S.; Rozenbaum, O.; Andreazza, P.; Rouet, J.-L. Evidence of a bacterial carbonate coating on plaster samples subjected to the Calcite Bioconcept biomineralization technique. Constr. Build. Mater. 2010, 24, 1036-1042. [CrossRef]

121. Siddique, R.; Chahal, N.K. Effect of ureolytic bacteria on concrete properties. Constr. Build. Mater. 2011, 25, 3791-3801. [CrossRef]

122. Erşan, Y.Ç.; Da Silva, F.B.; Boon, N.; Verstraete, W.; De Belie, N. Screening of bacteria and concrete compatible protection materials. Constr. Build. Mater. 2015, 88, 196-203. [CrossRef]

123. Dhami, N.K.; Reddy, M.S.; Mukherjee, A. Improvement in strength properties of ash bricks by bacterial calcite. Ecol. Eng. 2012, 39, 31-35. [CrossRef]

124. De Belie, N.; Wang, J. Bacteria-based repair and self-healing of concrete. J. Sustain. Cem. Mater. 2015, 5, 35-56. [CrossRef]

125. De Belie, N. Application of bacteria in concrete: A critical evaluation of the current status. RILEM Tech. Lett. 2016, 1, 56-61. [CrossRef] 
126. De Muynck, W.; Cox, K.; De Belie, N.; Verstraete, W. Bacterial carbonate precipitation as an alternative surface treatment for concrete. Constr. Build. Mater. 2008, 22, 875-885. [CrossRef]

127. Huseien, G.F.; Sam, A.R.M.; Faridmehr, I.; Baghban, M.H. Performance of Epoxy Resin Polymer as Self-Healing Cementitious Materials Agent in Mortar. Materials 2021, 14, 1255. [CrossRef] [PubMed]

128. Souradeep, G.; Kua, H.W. Encapsulation Technology and Techniques in Self-Healing Concrete. J. Mater. Civ. Eng. 2016, 28, 04016165. [CrossRef]

129. Zhang, Y.; Guo, H.; Cheng, X. Role of calcium sources in the strength and microstructure of microbial mortar. Constr. Build. Mater. 2015, 77, 160-167. [CrossRef]

130. Ramachandran, S.K.; Ramakrishnan, V.; Bang, S.S. Remediation of concrete using micro-organisms. ACI Mater. J.-Am. Concr. Inst. 2001, 98, 3-9.

131. Chahal, N.; Siddique, R.; Rajor, A. Influence of bacteria on the compressive strength, water absorption and rapid chloride permeability of concrete incorporating silica fume. Constr. Build. Mater. 2012, 37, 645-651. [CrossRef]

132. Nosouhian, F.; Mostofinejad, D.; Hasheminejad, H. Concrete Durability Improvement in a Sulfate Environment Using Bacteria. J. Mater. Civ. Eng. 2016, 28, 04015064. [CrossRef]

133. Achal, V.; Mukherjee, A.; Basu, P.C.; Reddy, M.S. Lactose mother liquor as an alternative nutrient source for microbial concrete production by Sporosarcina pasteurii. J. Ind. Microbiol. Biotechnol. 2008, 36, 433-438. [CrossRef]

134. Phung, Q.T.; Maes, N.; De Schutter, G.; Jacques, D.; Ye, G. Determination of water permeability of cementitious materials using a controlled constant flow method. Constr. Build. Mater. 2013, 47, 1488-1496. [CrossRef]

135. Siddique, R.; Nanda, V.; Kunal; Kadri, E.-H.; Khan, M.I.; Singh, M.; Rajor, A. Influence of bacteria on compressive strength and permeation properties of concrete made with cement baghouse filter dust. Constr. Build. Mater. 2016, 106, 461-469. [CrossRef]

136. Qiu, J.; Tng, D.Q.S.; Yang, E.-H. Surface treatment of recycled concrete aggregates through microbial carbonate precipitation. Constr. Build. Mater. 2014, 57, 144-150. [CrossRef]

137. Kim, H.; Park, S.; Han, J.; Lee, H. Microbially mediated calcium carbonate precipitation on normal and lightweight concrete. Constr. Build. Mater. 2013, 38, 1073-1082. [CrossRef]

138. Luo, M.; Qian, C.X. Performance of Two Bacteria-Based Additives Used for Self-Healing Concrete. J. Mater. Civ. Eng. 2016, 28, 04016151. [CrossRef]

139. Wiktor, V.; Jonkers, H. Quantification of crack-healing in novel bacteria-based self-healing concrete. Cem. Concr. Compos. 2011, 33, 763-770. [CrossRef]

140. Hammes, F.; Verstraete, W. Key roles of $\mathrm{pH}$ and calcium metabolism in microbial carbonate precipitation. Rev. Environ. Sci. Biotechnol. 2002, 1, 3-7. [CrossRef]

141. Jonkers, H.M.; Schlangen, E. Self-healing of cracked concrete: A bacterial approach. In Proceedings of the FRACOS6: Fracture Mechanics of Concrete and Concrete Structures, Catania, Italy, 17-22 June 2007; pp. 1821-1826.

142. da Silva, F.B.; De Belie, N.; Boon, N.; Verstraete, W. Production of non-axenic ureolytic spores for self-healing concrete applications. Constr. Build. Mater. 2015, 93, 1034-1041. [CrossRef]

143. Jonkers, H.M. Bacteria-Based Self-Healing Concrete. Heron 2021, 56, 1-12.

144. Wang, J.; Mignon, A.; Snoeck, D.; Wiktor, V.; Van Vliergerghe, S.; Boon, N.; De Belie, N. Application of modified-alginate encapsulated carbonate producing bacteria in concrete: A promising strategy for crack self-healing. Front. Microbiol. 2015, 6, 1088. [CrossRef] [PubMed]

145. Jensen, O.M. Use of superabsorbent polymers in concrete. Concr. Int. 2013, 35, 48-52.

146. Van Breugel, K. Is there a market for self-healing cement-based materials. In Proceedings of the First International Conference on Self-Healing Materials, Noordwijk aan Zee, The Netherlands, 18-20 April 2007.

147. Dong, B.; Wang, Y.; Fang, G.; Han, N.; Xing, F.; Lu, Y. Smart releasing behavior of a chemical self-healing microcapsule in the stimulated concrete pore solution. Cem. Concr. Compos. 2015, 56, 46-50. [CrossRef]

148. Blaiszik, B.; Caruso, M.; McIlroy, D.; Moore, J.; White, S.; Sottos, N. Microcapsules filled with reactive solutions for self-healing materials. Polymer 2008, 50, 990-997. [CrossRef]

149. Homma, D.; Mihashi, H.; Nishiwaki, T. Self-Healing Capability of Fibre Reinforced Cementitious Composites. J. Adv. Concr. Technol. 2009, 7, 217-228. [CrossRef]

150. Gupta, S. Development of high strength self compacting mortar with hybrid blend of polypropylene and steel fibers. Int. J. Eng. Technol. 2014, 4, 571-576.

151. Kua, H.W.; Koh, S. Sustainability Science Integrated Policies Promoting Interaction-Based Building Design Concept as a Climate Change Adaptation Strategy for Singapore and Beyond. In Green Growth: Managing the Transition to a Sustainable Economy; Springer: Berlin/Heidelberg, Germany, 2018; pp. 65-85.

152. Kua, H.W.; Kamath, S. An attributional and consequential life cycle assessment of substituting concrete with bricks. J. Clean. Prod. 2014, 81, 190-200. [CrossRef]

153. Gupta, S.; Kua, H.W. Factors Determining the Potential of Biochar as a Carbon Capturing and Sequestering Construction Material: Critical Review. J. Mater. Civ. Eng. 2017, 29, 04017086. [CrossRef]

154. Asaad, M.A.; Ismail, M.; Tahir, M.M.; Huseien, G.F.; Raja, P.B.; Asmara, Y.P. Enhanced corrosion resistance of reinforced concrete: Role of emerging eco-friendly Elaeis guineensis/silver nanoparticles inhibitor. Constr. Build. Mater. 2018, 188, 555-568. [CrossRef] 
155. Asaad, M.A.; Sarbini, N.N.; Sulaiman, A.; Ismail, M.; Huseien, G.F.; Majid, Z.A.; Raja, P.B. Improved corrosion resistance of mild steel against acid activation: Impact of novel Elaeis guineensis and silver nanoparticles. J. Ind. Eng. Chem. 2018, 63, 139-148. [CrossRef]

156. Onaizi, A.M.; Huseien, G.F.; Lim, N.H.A.S.; Amran, M.; Samadi, M. Effect of nanomaterials inclusion on sustainability of cement-based concretes: A comprehensive review. Constr. Build. Mater. 2021, 306, 124850. [CrossRef]

157. Samadi, M.; Shah, K.W.; Huseien, G.F.; Lim, N.H.A.S. Influence of Glass Silica Waste Nano Powder on the Mechanical and Microstructure Properties of Alkali-Activated Mortars. Nanomaterials 2020, 10, 324. [CrossRef] [PubMed]

158. Yunovich, M.; Thompson, N.G. Corrosion of highway bridges: Economic impact and control methodologies. Concr. Int. 2003, $25,52-57$.

159. Freyermuth, C.L. Life-cycle cost analysis for large bridges. Concr. Int. 2001, 23, 89-95.

160. Huseien, G.F.; Sam, A.R.M.; Algaifi, H.A.; Alyouef, R. Development of a sustainable concrete incorporated with effective microorganism and fly Ash: Characteristics and modeling studies. Constr. and Build. Materi. 2021, 285, 122899. [CrossRef]

161. Schlangen, E.; Joseph, C. Self-Healing Processes in Concrete. In Self-Healing Materials: Fundamentals, Design Strategies, and Applications; Wiley-VCH: Weinheim, Germany, 2009; pp. 1-307.

162. Asaad, M.A.; Raja, P.B.; Huseien, G.F.; Fediuk, R.; Ismail, M.; Alyousef, R. Self-healing epoxy coating doped with Elaesis guineensis/silver nanoparticles: A robust corrosion inhibitor. Constr. Build. Mater. 2021, 312, 125396. [CrossRef]

163. Samadi, M.; Huseien, G.F.; Lim, N.H.A.S.; Mohammadhosseini, H.; Alyousef, R.; Mirza, J.; Abd Rahman, A.B. Enhanced performance of nano-palm oil ash-based green mortar against sulphate environment. J. Build. Eng. 2020, 32, 101640. [CrossRef] 